\title{
Duration and determinants of delayed tuberculosis diagnosis and treatment in high-burden countries: a mixed-methods systematic review and meta-analysis
}

\author{
Alvin Kuo Jing Teo ${ }^{1,6^{*}+} \odot$, Shweta R. Singh ${ }^{1 \dagger}$, Kiesha Prem ${ }^{1,2+}$, Li Yang Hsu ${ }^{1,3}$ and Siyan Yi ${ }^{1,4,5}$
}

\begin{abstract}
Background: Thirty countries with the highest tuberculosis (TB) burden bear $87 \%$ of the world's TB cases. Delayed diagnosis and treatment are detrimental to TB prognosis and sustain TB transmission in the community, making TB elimination a great challenge, especially in these countries. Our objective was to elucidate the duration and determinants of delayed diagnosis and treatment of pulmonary TB in high TB-burden countries.

Methods: We conducted a systematic review and meta-analysis of quantitative and qualitative studies by searching four databases for literature published between 2008 and 2018 following PRISMA guidelines. We performed a narrative synthesis of the covariates significantly associated with patient, health system, treatment, and total delays. The pooled median duration of delay and effect sizes of covariates were estimated using random-effects meta-analyses. We identified key qualitative themes using thematic analysis.

Results: This review included 124 articles from 14 low- and lower-middle-income countries (LIC and LMIC) and five upper-middle-income countries (UMIC). The pooled median duration of delays (in days) were-patient delay (LIC/ LMIC: 28 (95\% CI 20-30); UMIC: 10 (95\% Cl 10-20), health system delay (LIC/LMIC: 14 (95\% Cl 2-28); UMIC: 4 (95\% Cl 2-4), and treatment delay (LIC/LMIC: 14 (95\% Cl 3-84); UMIC: 0 (95\% Cl 0-1). There was consistent evidence that being female and rural residence was associated with longer patient delay. Patient delay was also associated with other individual, interpersonal, and community risk factors such as poor TB knowledge, long chains of care-seeking through private/multiple providers, perceived stigma, financial insecurities, and poor access to healthcare. Organizational and policy factors mediated health system and treatment delays. These factors included the lack of resources and complex administrative procedures and systems at the health facilities. We identified data gaps in 11 high-burden countries.

Conclusions: This review presented the duration of delays and detailed the determinants of delayed TB diagnosis and treatment in high-burden countries. The gaps identified could be addressed through tailored approaches, education, and at a higher level, through health system strengthening and provision of universal health coverage to reduce delays and improve access to TB diagnosis and care.
\end{abstract}

\footnotetext{
*Correspondence: alvin.teo@aol.com

${ }^{\dagger}$ Alvin Kuo Jing Teo, Shweta R. Singh and Kiesha Prem have contributed equally to this work

1 Saw Swee Hock School of Public Health, National University of Singapore, National University Health System, Singapore, Singapore

Full list of author information is available at the end of the article
}

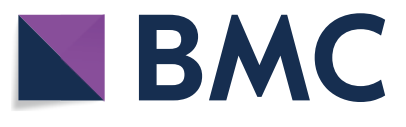

(c) The Author(s) 2021. Open Access This article is licensed under a Creative Commons Attribution 4.0 International License, which permits use, sharing, adaptation, distribution and reproduction in any medium or format, as long as you give appropriate credit to the original author(s) and the source, provide a link to the Creative Commons licence, and indicate if changes were made. The images or other third party material in this article are included in the article's Creative Commons licence, unless indicated otherwise in a credit line to the material. If material is not included in the article's Creative Commons licence and your intended use is not permitted by statutory regulation or exceeds the permitted use, you will need to obtain permission directly from the copyright holder. To view a copy of this licence, visit http://creativecommons.org/licenses/by/4.0/. The Creative Commons Public Domain Dedication waiver (http://creativeco mmons.org/publicdomain/zero/1.0/) applies to the data made available in this article, unless otherwise stated in a credit line to the data. 
PROSPERO registration: CRD42018107237.

Keywords: Tuberculosis, Patient delay, Health system delay, Treatment delay, Total delay, High burden countries, Risk factors

\section{Background}

In 1993, the World Health Organization (WHO) declared global tuberculosis (TB) emergency to make TB a high priority [1]. Twenty-five years on, TB remains one of the leading infectious causes of illness and death worldwide [2]. Despite that TB is both preventable and curable, and efforts such as the implementation of directly observed treatment short course and coordinated national TB programs worldwide, approximately 10 million people fell ill with $\mathrm{TB}$, of which 1.5 million died from the disease in 2018 [2]. The cumulative reduction in the TB incidence rate globally between 2015 and 2018 stood at $6 \%$ [2], imposing a significant delay in reaching the end TB milestone of $20 \%$ [3] reduction by 2020 . TB control and elimination are critical challenges in many countries. However, the burden is disproportionately borne by 30 countries, mostly in Asia and Africa, accounting for $87 \%$ of the world's TB (both pan-TB and drug-resistant TB) and $\mathrm{TB} / \mathrm{HIV}$ cases [2].

In 2018, nearly one-third of the people with TB were estimated to be undiagnosed globally [2]. The delay in diagnosis and treatment is detrimental to the patients' prognosis and perpetuates TB transmission in the community [4] and thus poses a great challenge to eliminating TB. Therefore, identifying the factors that lead to delayed TB diagnosis and treatment is imperative in developing interventions to reduce TB incidence substantially. Collectively, recent systematic reviews have provided empirical evidence associating sociodemographic, clinical, health system, and economic factors with delayed diagnosis and treatment of TB in different countries and regions [5-11]. However, delays in diagnosis and treatment vary across countries with a different burden of the disease. From what we know, no systematic reviews have addressed delayed diagnosis and treatment of TB among countries bearing most of the global TB burden. There is also a lack of reviews that triangulate qualitative and quantitative findings to provide a more complete and all-inclusive view of the matter. Therefore, a mixed-methods systematic review and meta-analysis were undertaken to derive the determinants and duration of diagnosis and treatment delays of pulmonary TB in the high TB-burden countries.

\section{Methods}

We structured this review following the Preferred Reporting Items for Systematic Reviews and MetaAnalysis (PRISMA)-statement [12]. The protocol of this systematic review has been published [13] and registered with the International Prospective Register of Systematic Reviews (PROSPERO) (Registration Number CRD42018107237).

\section{Inclusion and exclusion criteria}

In this review, we considered all studies conducted in the WHO high TB-burden countries-Angola, Bangladesh, Brazil, Cambodia, Central African Republic, China, Congo, Democratic People's Republic of Korea, Democratic Republic of Congo, Ethiopia, India, Indonesia, Kenya, Lesotho, Liberia, Mozambique, Myanmar, Namibia, Nigeria, Pakistan, Papua New Guinea, the Philippines, Russian Federation, Sierra Leone, South Africa, Tanzania, Thailand, Vietnam, Zambia, and Zimbabwe. We included studies that reported on individual and interpersonal risk factors, social and physical environment, health systems, and policies associated with delayed TB diagnosis and treatment initiation published between 2008 and 2018. The factors could be selfreported, ascertained by health providers, or abstracted from medical charts or programs/administrative records.

We included study populations comprising presumptive TB (persons presenting with signs and/or symptoms suggestive of TB) and people with TB (new diagnosis, previously treated, and those without a known history of previous TB treatment) regardless of HIV and bacteriological status. We included observational (crosssectional, case-control, retrospective, and prospective cohort design) and qualitative studies published in English or Chinese. Systematic reviews, meta-analyses, scoping reviews, intervention studies, publications in the form of letters and reviews, and studies lacking and/or unclear reporting of key outcomes were excluded.

Our primary outcomes were-(1) patient delay: the time interval between the onset of symptoms and the first encounter with healthcare professionals; (2) health system delay: the time interval between the first encounter with healthcare professionals and the diagnosis of pulmonary TB; (3) treatment delay: the time interval between TB diagnosis and TB treatment initiation; and (4) total delay: the time interval between onset of symptoms and TB treatment initiation. As there were no universal cut-offs [8] to a duration that constituted delay, we treated delay in this review as how they were defined in individual studies. We did not exclude studies based on the delay thresholds defined in individual studies. 


\section{Literature search strategy and study selection}

First, we conducted a preliminary search of articles on PubMed and EMBASE to develop a set of appropriate Medical Subject Heading terms, index terms, and keywords [13], centered around three domains (population/ problems: tuberculosis, outcomes: health-seeking behaviours; delays; barriers, countries: high burden countries). Using these identified search terms structured with Boolean logic operators (AND and OR), we contextualized the search strategies in PubMed, EMBASE, CINAHL, and PsycInfo (Additional file 1). The search fields included title, abstract, keywords, and text words. We also reviewed the reference list of key articles for additional studies. We managed all identified citations into EndNote X8 (Clarivate Analytics, Philadelphia, USA). Duplicates were removed, and the remainder was exported to Microsoft Excel (Microsoft Corporation, Washington, USA) for further assessment. AKJT and SRS independently screened the titles, abstracts, and full-text articles based on the inclusion and exclusion criteria. Interrater agreements for the titles and abstract screening between the reviewers were high (agreement $=98 \%$, Cohen's kappa $=0.95$, and Krippendorf alpha $=0.95$ ), and discrepancies were discussed. The two primary reviewers were able to resolve all the discrepancies without having to involve a third reviewer. The search and selection processes were conducted and presented in accordance with the PRISMA guidelines.

\section{Data extraction}

Study characteristics and data on risk factors were extracted independently by two authors (AKJT and SRS). We recorded study and participants' characteristics, exposure variables (various factors associated with delays reported by individual study), primary outcome measures, and study quality assessment scores using a standard form. Data on variables to be included in the meta-analysis were extracted by one author (AKJT) and subsequently reviewed by a second author (KP). This included duration of delay (median and interquartile range/range and mean and standard deviation) and the effect sizes (crude and adjusted odds ratios) for exposures of interest.

\section{Quality assessment}

The quality of the selected non-randomized (quantitative) and qualitative studies was critically evaluated using the Newcastle-Ottawa Scale for cross-sectional studies, case-control studies, and cohort studies, and the Critical Appraisal Skills Program (CASP) tool, respectively [14-16]. For non-randomized quantitative studies, the assessment was made based on four main domains(1) selection of samples (representativeness, sample size, definition and selection of cases and controls (for case-control studies), and non-response rate), (2) comparability of groups included in the analyses, (3) the ascertainment of exposures and outcomes, and (4) the statistical tests applied in the studies. A score of 1 was given to individual questions if the criterion was satisfied and 0 if the criterion was not satisfied or not justified. The highest possible score for cross-sectional studies was 10 (5 for selection, 2 for comparability, and 3 for outcomes). The highest possible score for case-control studies was 9 ( 4 for selection, 2 for comparability, and 3 for exposure). The highest possible score for cohort studies was 9 ( 4 for selection, 2 for comparability, and 3 for exposures). Studies that scored $0-3$ were regarded as low quality (LQ), 4-6 were regarded as moderate quality (MQ), and $\geq 7$ were regarded as high quality (HQ).

For qualitative studies, the assessment was made based on ten questions regarding the results, validity, and the value of the research. We gave a score of 1 if the paper fulfilled a criterion, 0.5 if we could not tell if the paper fulfilled a criterion, and 0 if the paper did not fulfill a criterion. A score of $0-5$ equated to LQ study, a score of 6-7 equated to MQ study, and a score of $\geq 8$ equated to HQ study. The final synthesized qualitative findings were graded based on the dependability and credibility of the findings using the ConQual approach [17].

\section{Data synthesis and analyses}

We described the studies by the populations, countries, study designs, and sample sizes. Countries were grouped by WHO region and categorized as low-income economies (LIC) - gross national income (GNI) per capita $\$ 1,025$ or less in 2018; lower-middle-income economies (LMIC)-GNI per capita between $\$ 1,026$ and \$3,995; upper-middle-income economies (UMIC) - GNI per capita between \$3,996 and \$12,375 according to World Bank classification in 2019 [18]. We reported the independent variables significantly associated with the patient, health system, treatment, and total delays. Results from the multivariable analyses preceded bivariate for studies that reported both bivariate and multivariable analyses.

Median and interquartile range/range for the duration of delays in days were extracted and used to estimate a pooled median, i.e., median of study-specific medians [19]. We pooled weighted medians by incorporating study-specific sample sizes [19]. For patient delay, we excluded two studies [20, 21] from China with sample sizes $>10,000$ because the pooled weighted medians were heavily skewed, including only estimates of the study with the largest sample size [21].

For independent variables (risk factors), effect sizes were extracted and used to calculate pooled odds ratios $(\mathrm{OR})$ and their $95 \%$ confidence interval (CI). We pooled 
effect sizes of covariates from studies that utilized similar delay thresholds if data were available in more than two studies and duration of delays by meta-analysis using $\mathrm{R}$ (R Foundation for Statistical Computing, Vienna). We pooled effect sizes for studies that defined patient delay using threshold values of $14-15$ days $(n=5), 20-21$ days $(\mathrm{n}=7), 28-30$ days $(\mathrm{n}=17)$; and health system delay using threshold values of $14-15$ days $(n=5)$. We found five studies that reported treatment delay using a threshold value of 7 days. However, the studies did not report similar covariates with effect sizes that allowed pooling. Where adjustments for covariates had been performed, the data from the adjusted model were pooled.

We quantified between-study heterogeneity using Chi-square statistic $\mathrm{Q}, \mathrm{I}^{2}$, and Tau [22]. We estimated the pooled OR and its $95 \%$ CI using a Bayesian randomeffect model for each meta-analysis, which accounted for between-study heterogeneity [23]. The estimates for Tau and $\mathrm{I}^{2}$ statistics were presented together with the pooled estimates and the $95 \% \mathrm{CI}$. We used the inverse of the effect size variance to determine the pooling weights. We assessed the association of the primary outcomes and (1) sociodemographic and economic variables: sex, urbanicity; (2) behavioral variables: smoking, alcohol use, TB knowledge; and (3) clinical and health servicesrelated variables: hemoptysis, weight loss, fever, chest pain, night sweats in the meta-analyses.

We extracted qualitative findings and sample quotes reported in qualitative and mixed-method studies verbatim. The extracted data were annotated and analyzed using NVIVO 12 (QSR International). We retrieved references deductively and applied thematic analyses to categorize the textual references. Two authors (AKJT and SRS) coded the data independently. Discrepancies, code definitions, and the emergence of sub-themes were discussed. The results were presented by income categories that the high-burden countries represent.

\section{Results}

\section{Study selection}

The systematic review process is presented in Fig. 1. A total of 4878 records were identified from electronic database searches. Following the removal of duplicates $(\mathrm{n}=1189)$ and non-relevant records $(\mathrm{n}=3383), 306$ records were assessed for eligibility. Of these, 182 articles were further excluded. Finally, 124 articles were reviewed. A qualitative synthesis was performed for 36 studies. We conducted quantitative and narrative synthesis on 86 studies. Two mixed-method studies underwent both qualitative and quantitative/narrative synthesis. We found large heterogeneity among studies included in the meta-analyses -1 (7\%) had $\mathrm{I}^{2} \leq 50 \%, 14$ (93\%) had $\mathrm{I}^{2}>50 \%$, and $13(87 \%)$ had $\mathrm{I}^{2}>75 \%$.

\section{Study characteristics and quality assessments}

These studies described data from 18,759 presumptive TB and 131,142 people with ТВ [20, 21, 24-109], 1659 in-depth and structured interviews, and 87 focus groups [48, 96, 110-145] from 19 countries in three continents (Table 1). A total of 14 countries were classified as lowerincome (LIC) and lower-middle-income economies (LMIC), and five were classified as upper-middle-income economies (UMIC) [18]. Patient delay was reported in 103 studies, health system delay in 29 studies, treatment delay in 18 studies, and total delay in 21 studies. Of the 30 high TB-burden countries, 11 countries were not included in this review, either due to data unavailability or lack of key outcome data (Fig. 2). After assessments of study quality, a total of $81 \mathrm{HQ}$ studies, $40 \mathrm{MQ}$ studies, and one LQ study were identified. Two mixed-methods studies scored MQ/HQ and $\mathrm{HQ} / \mathrm{MQ}$ for the quantitative and qualitative components, respectively. The final synthesized qualitative findings were rated HQ (55\%) and MQ (45\%) using the ConQual method. Details of the assessments were illustrated in the Additional file 1. No studies were excluded based on the outcome of quality assessments; instead, the information was considered during data synthesis and interpretation.

\section{Patient delay}

The pooled median patient delay (Fig. 3) in LIC and LMIC was 28 days (95\% CI 17-30). The pooled median patient delay in UMIC was 10 days (95\% CI 10-20). The overall median patient delay in high TB burden countries was 16 days (95\% CI 11-20). In the meta-analysis and narrative synthesis of quantitative data (Table 2), females (pooled OR 1.48. 95\% CI 1.09-1.98, $\mathrm{P}=0.01$ ) were more likely to delay care-seeking for TB (Fig. 4). Qualitative studies highlighted limitations for women to seek healthcare $[115,117,125,126,130]$. Women reported economic constraints and power imbalances in the decision-making process as barriers to care-seeking $[115,117,125$, 126]. We further stratified the analysis by sex. We found that women were disproportionately affected by risk factors for patient delay (Fig. 5), such as unemployment, poor TB knowledge, and difficulties traveling a long distance to visit health facilities $[43,51]$. Long-distance to health facilities was also reported by qualitative studies as a barrier to care-seeking $[48,111,112,114,117,126$, $131,136,137,140,142,145]$. In addition to physical barriers, financial insecurities and economic challenges also compounded patient delay $[20,25,28,33,38-40,43,50$, $51,66,67,69,72,76,77,83,87,88]$. Among qualitative studies (Table 3), seven articles reflected on participant's experiences where competing priorities of livelihoods and commitment to work and family led to individual care-seeking delay $[48,125-127,134,138,145]$. We 


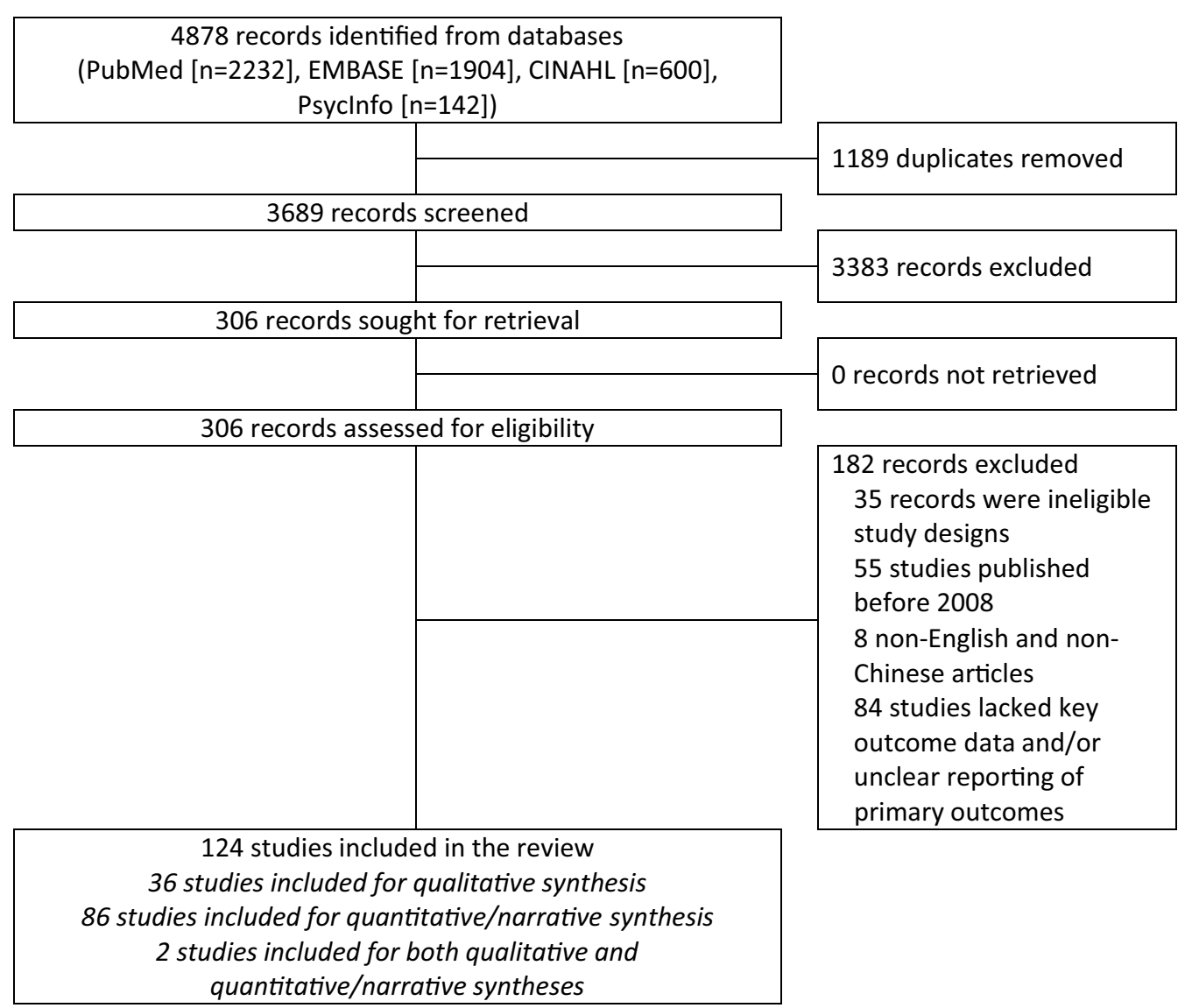

Fig. 1 PRISMA flow diagram for identification of studies via databases

also found that being rural residents in LIC and LMIC (Table 2 and Fig. 4) was associated with patient delay (pooled OR 1.75, 95\% CI 1.01-2.94, $\mathrm{P}=0.02$ ). No studies from the UMIC were included in the meta-analysis for urbanicity. This review also reported other sociodemographic and economic risk factors for patient delay, such as lower education level and being older, unmarried, and unemployed. High indirect medical costs [48, 126], absence of health insurance, productivity, time, and income loss $[48,125,127,134,138,145]$ resulting from disease suffering further worsen household vulnerabilities and contribute to a delay in TB diagnosis and poor health outcomes (Table 2) [146].

Furthermore, poor TB knowledge (Table 2), unawareness of free TB treatment policies [30], low perceived susceptibility, and severity of $\mathrm{TB}$ was associated with patient delay $[40,48,110,113-115,117,119,124,126$, 137]. However, the pooled estimates for TB knowledge (delay thresholds 21 days-(pooled OR 0.91, 95\% CI 0.24-2.71, $\mathrm{P}=0.62$ ) and 28 days-(pooled OR 1.36, 95\% CI $0.39-4.83, \mathrm{P}=0.25$ ) were not significantly associated with patient delay in the meta-analysis (Fig. 6).
Perceived stigma and discrimination (Table 3) at the workplace, within the family, and community and associating TB with HIV deterred presumptive TB patients from care-seeking $[110,114-117,121,125-130,135-$ 137, 139-144]. From the qualitative data, we found studies that explained the use of alcohol and smoking to conceal health issues, especially among men, which resulted in delayed care-seeking $[116,128,137,138,144$, 145]. However, these lifestyle behaviors were not statistically significant in the meta-analysis, where the estimates from both sexes were pooled (Fig. 6). Several studies in Africa [110, 113, 114] highlighted superstitious beliefs that TB is caused by divine retributions of past misdeeds, sinful behaviors, and curses; thus, help is first sought from traditional or spiritual healers instead of a health provider. Besides, studies in Asia reported the misconception that TB is hereditary $[117,126]$.

Long chains of care-seeking through multiple nonformal or private health providers were also reported as a determinant of patient delay [110-128, 134, 135, 137, 138, 140, 142-144]. Qualitative data also suggested that the lack of trust in the public health care system 
Table 1 Characteristics of included observational and qualitative studies

\begin{tabular}{|c|c|c|c|c|c|c|}
\hline \multirow[t]{3}{*}{ Income group* } & \multirow[t]{3}{*}{ Country } & \multirow[t]{3}{*}{ Study population } & \multirow[t]{3}{*}{ Study design } & \multicolumn{3}{|l|}{ Sample size and study } \\
\hline & & & & \multicolumn{3}{|c|}{ Newcastle-Ottawa scale score ${ }^{\dagger}$} \\
\hline & & & & HQ & MQ & LQ \\
\hline \multicolumn{7}{|l|}{ Patient delay } \\
\hline \multirow[t]{6}{*}{ LIC } & Ethiopia & People with TB & Cross-sectional & $\begin{array}{l}216[24], 296[25], 360[26], \\
382[27], 398[28], 425[29], \\
605[30], 706[31], 924[32]\end{array}$ & $129[33], 201[34], 226[35]$ & \\
\hline & & \multirow{2}{*}{$\begin{array}{l}\text { People with presump- } \\
\text { tive TB }\end{array}$} & Case-control & $838[36]$ & & \\
\hline & & & Cross-sectional & $\begin{array}{l}476[37], 843[38] \\
1006[39]\end{array}$ & $663[40], 763[41]$ & \\
\hline & Mozambique & People with TB & Cross-sectional & & $622[42]$ & \\
\hline & Tanzania & People with TB & Cross-sectional & $639[43]$ & $206[44]$ & \\
\hline & & $\begin{array}{l}\text { People with presump- } \\
\text { tive TB }\end{array}$ & Cross-sectional & $3388[45]$ & & \\
\hline \multirow[t]{12}{*}{ LMIC } & Angola & People with TB & Cross-sectional & $385[46]$ & & \\
\hline & Bangladesh & People with TB & Cross-sectional & & $7280[47]$ & \\
\hline & Cambodia & People with TB & Mixed-methods & & $96[48]$ & \\
\hline & India & People with TB & Cross-sectional & $216[49], 234[50]$ & $150[51], 261[52]$ & \\
\hline & & People with TB (children) & Cross-sectional & & $175[53]$ & \\
\hline & & $\begin{array}{l}\text { People with presump- } \\
\text { tive TB }\end{array}$ & Cross-sectional & $437[54]$ & & \\
\hline & Indonesia & $\begin{array}{l}\text { People with presump- } \\
\text { tive TB }\end{array}$ & Cross-sectional & $194[55]$ & $746[56]$ & \\
\hline & Kenya & People with TB & Cross-sectional & & & $230[57]$ \\
\hline & & $\begin{array}{l}\text { People with presump- } \\
\text { tive TB }\end{array}$ & Cross-sectional & & $426[58]$ & \\
\hline & Nigeria & People with TB & Cross-sectional & $160[59], 450[60]$ & $102[61]$ & \\
\hline & Zambia & $\begin{array}{l}\text { People with presump- } \\
\text { tive TB }\end{array}$ & Cross-sectional & $6708[62]$ & & \\
\hline & Zimbabwe & People with TB & Cross-sectional & $383[63]$ & & \\
\hline \multirow[t]{11}{*}{ UMIC } & Brazil & People with TB & Cross-sectional & $139[64], 153[65]$ & $\begin{array}{l}97[66], 101[67], 199[68], \\
218[69], 304[70]\end{array}$ & \\
\hline & & TB-HIV co-infection & Prospective cohort & $201[71]$ & & \\
\hline & China & People with TB & Cross-sectional & $\begin{array}{l}314[72], 1126[73], \\
2280[74]\end{array}$ & $\begin{array}{l}146[75], 259[76] \\
314[77], 323[78] \\
819[79], 1083[80]\end{array}$ & \\
\hline & & & Prospective cohort & & 202[81] & \\
\hline & & & Retrospective cohort & 4677[82], 10356[20] & $75401[21]$ & \\
\hline & & $\begin{array}{l}\text { People with presump- } \\
\text { tive TB }\end{array}$ & Cross-sectional & & $1005[83]$ & \\
\hline & Russia & People with TB & Cross-sectional & $105[84]$ & & \\
\hline & South Africa & General population & Cross-sectional & & $1020[85]$ & \\
\hline & & $\begin{array}{l}\text { People with presump- } \\
\text { tive TB }\end{array}$ & Cross-sectional & & $104[86]$ & \\
\hline & & TB-HIV co-infection & Prospective cohort & $891[87]$ & & \\
\hline & Thailand & People with TB & Cross-sectional & $443[88]$ & $199[89]$ & \\
\hline \multicolumn{7}{|c|}{ Health system delay } \\
\hline \multirow[t]{2}{*}{ LIC } & Ethiopia & People with TB & Cross-sectional & & $201[34]$ & \\
\hline & Nigeria & People with TB & Cross-sectional & $470[90]$ & & \\
\hline LMIC & Angola & People with TB & Cross-sectional & $385[46]$ & & \\
\hline
\end{tabular}


Table 1 (continued)

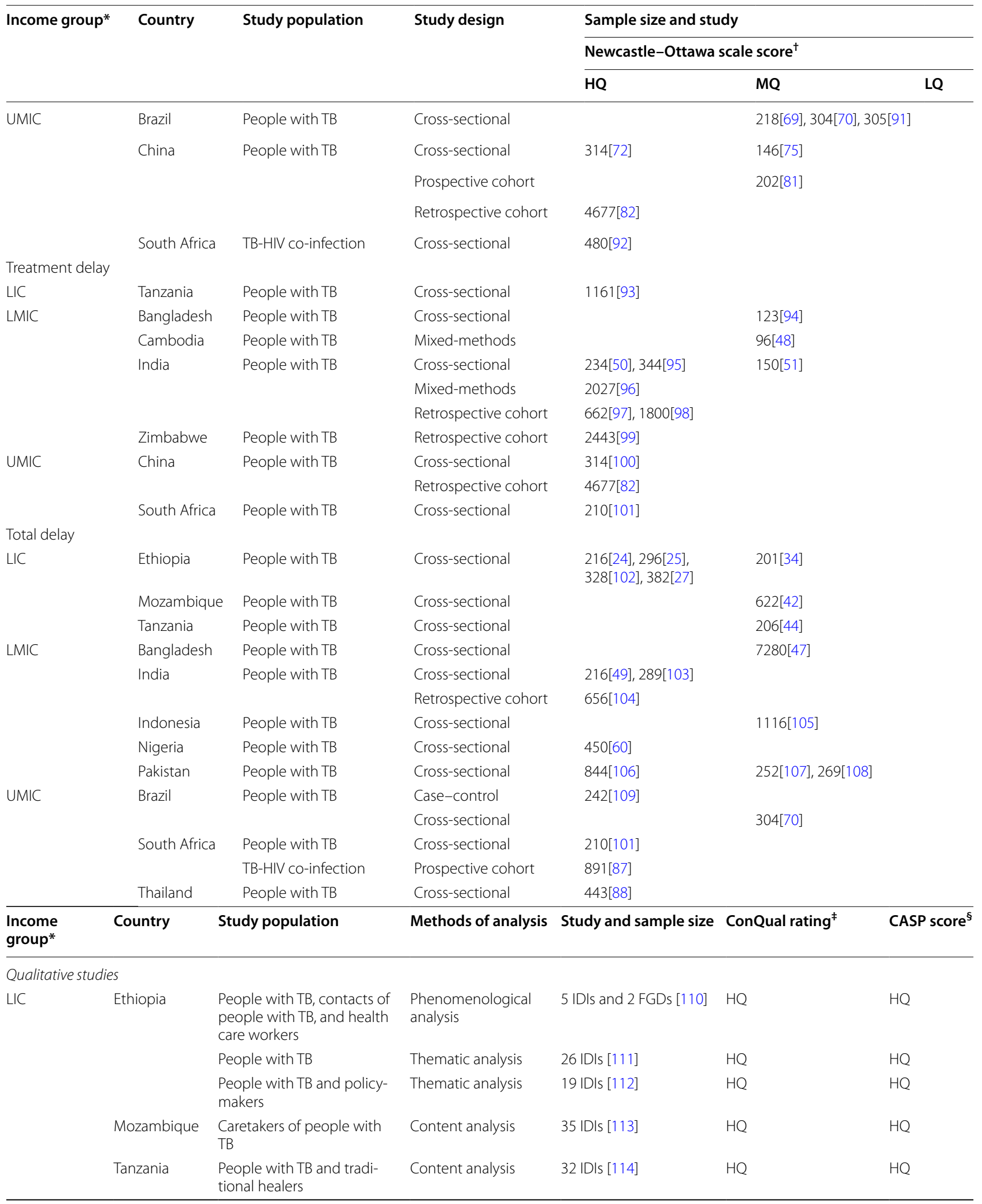


Table 1 (continued)

\begin{tabular}{|c|c|c|c|c|c|c|}
\hline $\begin{array}{l}\text { Income } \\
\text { group* }\end{array}$ & Country & Study population & Methods of analysis & Study and sample size & ConQual rating $^{\ddagger}$ & CASP score ${ }^{\S}$ \\
\hline \multirow[t]{16}{*}{ LMIC } & Bangladesh & People with TB & $\begin{array}{l}\text { Qualitative analysis } \\
\text { of open-ended } \\
\text { survey questions }\end{array}$ & 229 interviews [115] & MQ & MQ \\
\hline & & $\begin{array}{l}\text { People with TB and health } \\
\text { care workers }\end{array}$ & $\begin{array}{l}\text { Qualitative analysis } \\
\text { using apriori codes }\end{array}$ & 24 IDIs [116] & $\mathrm{HQ}$ & $\mathrm{HQ}$ \\
\hline & Cambodia & $\begin{array}{l}\text { People with TB, health care } \\
\text { workers, and community } \\
\text { volunteers }\end{array}$ & Thematic analysis & 43 IDls and 6 FGDs [48] & MQ & $\mathrm{HQ}$ \\
\hline & & $\begin{array}{l}\text { People with TB and the } \\
\text { general population }\end{array}$ & & 13 FGDs [117] & $\mathrm{HQ}$ & $\mathrm{HQ}$ \\
\hline & India & Health care workers & Thematic analysis & 16 IDIs [118] & $\mathrm{HQ}$ & $\mathrm{HQ}$ \\
\hline & & People with TB & $\begin{array}{l}\text { Not presented in the } \\
\text { article }\end{array}$ & $\begin{array}{l}76 \text { IDIs [1 19], } 75 \text { struc- } \\
\text { tured interviews [96] }\end{array}$ & MQ & MQ \\
\hline & & & & $\begin{array}{l}108 \text { structured inter- } \\
\text { views [120] }\end{array}$ & MQ & $\mathrm{HQ}$ \\
\hline & & & $\begin{array}{l}\text { Qualitative analysis of } \\
\text { open-ended } \\
\text { survey questions }\end{array}$ & 229 interviews [115] & MQ & MQ \\
\hline & & $\begin{array}{l}\text { People with TB and health } \\
\text { care workers }\end{array}$ & $\begin{array}{l}\text { Qualitative analysis } \\
\text { using apriori codes }\end{array}$ & 19 IDIs [121] & MQ & $\mathrm{HQ}$ \\
\hline & & & Thematic analysis & 71 IDIs [122] & $\mathrm{HQ}$ & $\mathrm{HQ}$ \\
\hline & Indonesia & $\begin{array}{l}\text { People with TB and com- } \\
\text { munity volunteers }\end{array}$ & Thematic analysis & $\begin{array}{l}67 \mathrm{IDIs} \text { and } 6 \text { FGDs } \\
\text { [123] }\end{array}$ & $\mathrm{HQ}$ & $\mathrm{HQ}$ \\
\hline & & $\begin{array}{l}\text { People with TB, TB survivors, } \\
\text { village leaders, and com- } \\
\text { munity volunteers }\end{array}$ & $\begin{array}{l}\text { Not presented in the } \\
\text { article }\end{array}$ & $\begin{array}{l}50 \mathrm{IDIs} \text { and } 3 \text { FGDs } \\
{[124]}\end{array}$ & $\mathrm{HQ}$ & $\mathrm{HQ}$ \\
\hline & Nigeria & General population & Thematic analysis & 56 IDIs [125] & $\mathrm{MQ}$ & $\mathrm{HQ}$ \\
\hline & Philippines & $\begin{array}{l}\text { People with TB and the } \\
\text { general population }\end{array}$ & Thematic analysis & $\begin{array}{l}22 \mathrm{IDIs} \text { and } 3 \mathrm{FGDs} \\
{[126]}\end{array}$ & $\mathrm{HQ}$ & $\mathrm{HQ}$ \\
\hline & Zambia & $\begin{array}{l}\text { People with TB and com- } \\
\text { munity volunteers }\end{array}$ & Thematic analysis & $\begin{array}{l}30 \mathrm{IDIs} \text { and } 6 \text { FGDs } \\
{[127]}\end{array}$ & MQ & $\mathrm{HQ}$ \\
\hline & Zimbabwe & People with presumptive TB & Grounded theory & 20 IDIs [128] & $\mathrm{HQ}$ & $\mathrm{HQ}$ \\
\hline \multirow[t]{8}{*}{ UMIC } & Brazil & Health care workers & Discourse analysis & 16 IDIs [129] & $\mathrm{MQ}$ & $\mathrm{HQ}$ \\
\hline & & People with TB & Content analysis & 23 IDIs [130] & $\mathrm{MQ}$ & $\mathrm{HQ}$ \\
\hline & & & Thematic analysis & 7 IDls [131] & MQ & $\mathrm{HQ}$ \\
\hline & & & Discourse analysis & 7 IDIs [132] & $\mathrm{HQ}$ & MQ \\
\hline & China & People with TB & $\begin{array}{l}\text { Qualitative analysis of } \\
\text { open-ended } \\
\text { survey questions }\end{array}$ & 70 interviews [133] & MQ & MQ \\
\hline & & People with TB (migrants) & Thematic analysis & 34 IDIs [134] & $\mathrm{MQ}$ & $\mathrm{HQ}$ \\
\hline & & $\begin{array}{l}\text { People with TB (migrants), } \\
\text { People with presumptive } \\
\text { TB, and health care workers }\end{array}$ & $\begin{array}{l}\text { Framework } \\
\text { approach }\end{array}$ & $\begin{array}{l}60 \mathrm{IDIs} \text { and } 12 \mathrm{FGDs} \\
{[135]}\end{array}$ & MQ & $\mathrm{HQ}$ \\
\hline & & $\begin{array}{l}\text { People with TB, health care } \\
\text { workers, policymakers, and } \\
\text { community volunteers }\end{array}$ & Thematic analysis & $\begin{array}{l}47 \text { IDls and } 5 \text { FGDs } \\
\text { [136] }\end{array}$ & MQ & $\mathrm{HQ}$ \\
\hline
\end{tabular}


Table 1 (continued)

\begin{tabular}{|c|c|c|c|c|c|c|}
\hline $\begin{array}{l}\text { Income } \\
\text { group* }\end{array}$ & Country & Study population & Methods of analysis & Study and sample size & ConQual rating $^{\ddagger}$ & CASP score $^{\S}$ \\
\hline & \multirow[t]{2}{*}{ Russia } & People with TB & Grounded theory & 5 FGDs [137] & $\mathrm{HQ}$ & $\mathrm{HQ}$ \\
\hline & & $\begin{array}{l}\text { People with TB and health } \\
\text { care workers }\end{array}$ & & $\begin{array}{l}32 \text { IDIs and } 11 \text { partici- } \\
\text { pants in FGDs (number } \\
\text { of FGDs not specified) } \\
\text { [138] }\end{array}$ & $\mathrm{HQ}$ & $\mathrm{HQ}$ \\
\hline & \multirow[t]{6}{*}{ South Africa } & $\begin{array}{l}\text { Contacts of people with } \\
\text { TB, health care workers, } \\
\text { policymakers, and people } \\
\text { with TB (miners) }\end{array}$ & $\begin{array}{l}\text { Thematic analysis } \\
\text { and grounded theory }\end{array}$ & $\begin{array}{l}104 \text { applied ethnogra- } \\
\text { phy using formal/infor- } \\
\text { mal IDIs, FGDs, field } \\
\text { notes, and participant } \\
\text { observations [139] }\end{array}$ & $\mathrm{HQ}$ & $\mathrm{HQ}$ \\
\hline & & $\begin{array}{l}\text { Health care workers, village } \\
\text { leaders, and researchers }\end{array}$ & Thematic analysis & 12 IDIs [140] & $\mathrm{HQ}$ & $\mathrm{HQ}$ \\
\hline & & People with TB & & 41 IDls [141] & MQ & $\mathrm{HQ}$ \\
\hline & & $\begin{array}{l}\text { People with TB, contacts of } \\
\text { people with TB, and health } \\
\text { care workers }\end{array}$ & & $\begin{array}{l}25 \text { IDIs and } 4 \text { FGDs } \\
{[142]}\end{array}$ & $\mathrm{HQ}$ & $\mathrm{HQ}$ \\
\hline & & $\begin{array}{l}\text { People with TB, the general } \\
\text { population, and community } \\
\text { volunteers }\end{array}$ & & $\begin{array}{l}93 \text { reports from par- } \\
\text { ticipatory research and } \\
\text { participants observa- } \\
\text { tion [143] }\end{array}$ & $\mathrm{HQ}$ & $\mathrm{HQ}$ \\
\hline & & $\begin{array}{l}\text { People with TB and general } \\
\text { population }\end{array}$ & $\begin{array}{l}\text { Thematic analysis } \\
\text { and grounded theory }\end{array}$ & 8 IDls [144] & $\mathrm{HQ}$ & $\mathrm{HQ}$ \\
\hline & Thailand & $\begin{array}{l}\text { People with TB (migrants) } \\
\text { and health care workers }\end{array}$ & Thematic analysis & $\begin{array}{l}12 \text { IDIs and } 11 \text { FGDs } \\
{[145]}\end{array}$ & MQ & $\mathrm{HQ}$ \\
\hline
\end{tabular}

Each number at the normal line of type in each cell referred to the sample size of each discrete study that shared the respective characteristics (country, study population, study design, and study quality). The number/s in bracket indicate the source article/s. Blank cells indicated that no studies of a particular set of characteristics were identified and included in this review

CASP critical appraisal skills program; FGD focus group discussions; $H Q$ high quality, IDI in-depth interviews; $L I C$ low-income countries, $L M I C$ lower-middle-income countries, LQ low quality; MQ moderate quality, TB tuberculosis, UMIC upper-middle-income countries,

*Based on World Bank classification. Low-income economies-gross national income (GNI) per capita \$1,025 or less in 2018; lower-middle-income economies-GNI per capita between $\$ 1,026$ and $\$ 3,995$; upper-middle-income economies-GNI per capita between $\$ 3,996$ and $\$ 12,375$

† Study quality was assessed using the Newcastle-Ottawa scale. The highest possible score for cross-sectional studies was 10 ( 5 for selection, 2 for comparability, and 3 for outcome). The highest possible score for case-control studies was 9 ( 4 for selection, 2 for comparability, and 3 for exposure). The highest possible score for cohort studies was 9 (4 for selection, 2 for comparability, and 3 for exposure). Studies that scored 0-3 were regarded as LQ, 4-6 were regarded as MQ, and $\geq 7$ were regarded as $\mathrm{HQ}$

${ }^{\ddagger}$ All papers were pre-ranked (high, moderate, low), and the levels were adjusted according to the dependability and credibility of the findings. We pre-ranked all papers as high. The ranking remained high if the papers were regarded as dependable, and the findings were unequivocal. We downgraded the paper from high to moderate if the papers scored 3 or less in terms of dependability or scored a mix of unequivocal and credible in terms of credibility

${ }^{\S}$ CASP for qualitative study had 10 questions to appraise the paper critically. We gave a score of 1 if the paper fulfilled a criterion, 0.5 if we could not tell if the paper fulfilled a criterion, and 0 if it did not fulfil a criterion. A score of $0-5$ equated to LQ study, a score of 6-7 equated to MQ study, and a score of $\geq 8$ equated to HQ study

perpetuated delays in care-seeking [122, 131, 136-139, 143, 144]. The inability of people with TB to recognize symptoms such as fever and cough that were not ascribed to TB intrinsically led to self-medication and treatment or waiting for symptoms to self-resolve due to low perceived disease severity $[110,119,126,128,129,134,137$, $140,142]$. Studies reported that the presence of cough $[69,70,74,80,86,88]$ was associated with patient delay compared to hemoptysis and weight loss that were perceived to be more severe (Table 2). However, the relationships between TB symptoms and patient delay were not statistically significant in the meta-analysis (Fig. 7).

\section{Health system delay}

The pooled median health system delay (Fig. 8) in LIC and LMIC was 14 days (95\% CI 2-28). The pooled median health system delay in UMIC was 4 days (95\% CI $2-4)$. The overall median health system delay in high TBburden countries was 4 days (95\% CI 2-4). We explored the association between sex and health system delay, 


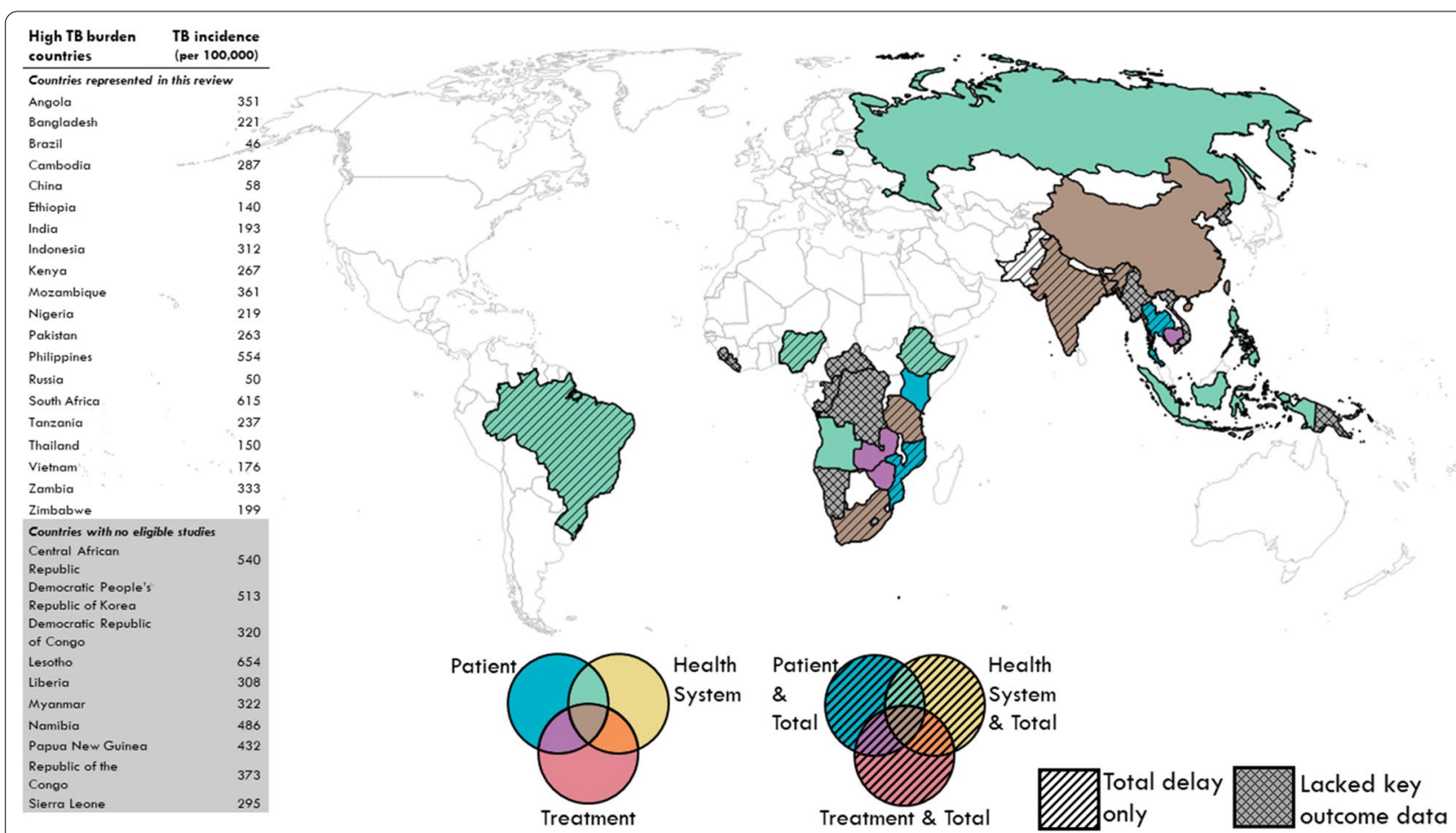

Fig. 2 Geographical coverage of studies published between 2008 and 2018 included in this systematic review of delayed diagnosis and treatment of pulmonary tuberculosis. The 30-high tuberculosis (TB) burden countries which have been designated by the World Health Organization are outlined in black. Of them, countries with studies presenting various types of delay are categorized by the various colors. For example, countries shaded in green had studies presenting both patient and health system delay, and those with diagonal strips presented total delay too. Some of the high TB burden countries shaded in grey had no studies identified here or lacked key outcome data. The table on the left represents the TB incidence per 100,000 population of high TB burden countries in 2019. Rows shaded in grey represent countries that were not included in this review either due to data unavailability or lack of key outcome data

and we did not find a significant relationship (Additional file 1). Twelve qualitative studies reported that poor practices and ignorance of TB among health providers at health facilities led to a delay in TB diagnosis $[110,111$, $114,116,118,122-124,129,132,133,135]$. Seven qualitative studies explained that complicated administrative procedures at the health facilities $[96,119,126,130,132$, 133, 144], which could have resulted in longer waiting time [46], and complex referral system[144] that eventually prolonged health system delay. This review identified studies reporting that health system delays were associated with visiting lower-level facilities that did not provide TB services [34, 46, 72, 75, 90]. Six qualitative studies mentioned that inadequate resources and supplies in health facilities could have delayed TB diagnosis $[96,129,130,132,138,144]$. Three quantitative studies reported that people with smear-negative TB were more likely to experience health system delay $[81,82,91]$.

\section{Treatment delay}

The pooled median treatment delay (Fig. 8) in LIC and LMIC was 14 days (95\% CI 3-84). The pooled median treatment delay in UMIC was 0 days $(95 \%$ CI $0-1)$. The overall median treatment delay in high TB burden countries was 1 day (95\% CI 0-14). One qualitative study noted that the geographical distance to health facilities, especially when treatment was initiated in separate institutions, delayed TB treatment initiation [141]. This could be exacerbated by residing in areas without health centers nearby [97]. Health system factors such as logistical issues in drug transportation $[96,141]$ and the absence of TB diagnostic services in local health facilities $[96,119]$ compounded delay in treatment initiation. Like patient delay, a qualitative study provided insights into TB stigma experienced by women resulting in the concealment of diagnosis, expulsion from their community, or isolation; thus, delaying access to TB care and treatment[127]. Four qualitative studies mentioned self-perception of health, unconvinced diagnosis and need for TB treatment, and the perceived low effectiveness of TB treatment led to a delay in TB treatment initiation $[48,96,119,141]$. We also found that retreatment cases were more likely to delay TB treatment initiation [94-98]. 


\section{Discussion}

Our review is the first to focus on determinants of delayed TB diagnosis and treatment among high TB burden countries using evidence-based quantitative and qualitative information. Studies from high TB-burden LIC/LMIC reported longer median patient delay (28 days) than UMIC (10 days). Our findings were consistent with previous systematic reviews conducted in countries of different income levels $[5,8]$. However, the median patient delay among UMIC in this review was shorter than the findings from observational studies conducted in other high-income countries [147, 148]. TB burden in high-income countries has been progressively reduced through improvements in socio-economic conditions, strong health systems components such as the delivery of TB services and universal health coverage, and social protection schemes [149]. Nevertheless, the high standards of living and wellbeing have shaped the notion that TB is not a significant concern, rendering a lower index of suspicion of $\mathrm{TB}$ and thus delaying TB care-seeking [150]. Notwithstanding, TB remains an issue, especially among hard-to-reach populations living in high-income settings like migrants [151, 152], who face challenges in accessing healthcare due to stigma, language barriers, and cost of testing and treatment [6].

The median health system delay in this review (LIC/ LMIC: 14 days and UMIC: 4 days) was found to be shorter than previous systematic reviews conducted among countries of similar economies [5, 8]. As this review included studies conducted in the last decade, the improvement in health system delay may be attributed to the enhancements of healthcare systems [153] and the quality of TB laboratories [154]. The clinicians' ability to consider TB as a differential diagnosis in high burden settings is also essential for early diagnosis and treatment [155]. However, there remains a paucity of data in several high TB burden countries, including seven in Africa (Central African Republic, Democratic Republic of Condo, Lesotho, Liberia, Namibia, Republic of the Congo, and Sierra Leone) and four in Asia (Democratic People's Republic of Korea, Myanmar, Papua New Guinea, and Vietnam), potentially due to logistical challenges in conducting such studies.

\section{Patient delay}

While TB is a disease mainly affecting men[156], in our review, we found that women faced challenges in accessing TB care promptly in some settings due to resource constraints, power imbalances, and poor TB knowledge. However, there was a paucity of sex-specific data on the determinants of delay in TB diagnosis and treatment. It is imperative to recognize sex disparities in TB care-seeking. Women with TB in high burden countries experienced delays in diagnosis and treatment because of barriers to TB services. Therefore, future studies should report disaggregated data by sex to inform programs and interventions addressing sex-specific vulnerabilities in improving access to TB services among men and women.

Despite wide coverage of free TB diagnostic and treatment services in high burden countries [157], people with TB and their families, especially the poor, bear the impact of high economic costs [158]. Studies included in our review also reported that livelihood, work, and family were prioritized and led to a delay in care-seeking. These factors, coupled with the physical environments and impoverished living conditions [127, 138], plunged low-income households into a vicious cycle of impoverishments $[159,160]$, making TB elimination overtly challenging. Aside from the broad expansion of TB services that have been shown to reduce the financial burden on TB-affected households [161], it is also essential to ensure that financial and social protection policies are in place to protect those at risk of catastrophic TB costs and poverty.

Our pooled estimates showed that rural dwellers were significantly associated with patient delay. In the rural setting, access to healthcare facilities, particularly an institution that offers TB diagnostic services, might be lacking [5]. Rural populations were also more likely to have a lower health literacy [162], resulting in poorer health status and outcomes [163]. Nevertheless, the concept of urban-rural is dynamic and context-dependent, driven by migration, population, and economic growth over time [164]. The consistent findings of rural residence and patient delay in $\mathrm{TB}[5,8,165]$ suggest increased efforts tailored to the country's specific circumstances in reaching the affected communities are required.

\footnotetext{
(See figure on next page.)

Fig. 3 Duration of patient delay by regions reported in high tuberculosis burden countries. Countries were grouped by WHO regions (AFR African region, AMR Region of the Americas, SEAR South-East Asia region, WPR Western Pacific region). Countries were also categorized as (i) LIC (low-income countries), (ii) LMIC (low-middle income countries), or (ii) UMIC (upper-middle income countries) as designated by the World Bank in 2019. Studies from LIC and LMIC were in bold. Patient delay (in blue) was pooled by the countries' economic status using Weighted Medians of Medians methods by McGrath (2019). The estimates were weighted by sample sizes of the studies. Pooled results for LIC and LMIC were not presented separately due to insufficient studies from LIC. Duration of delay in days were presented in the log scale
} 


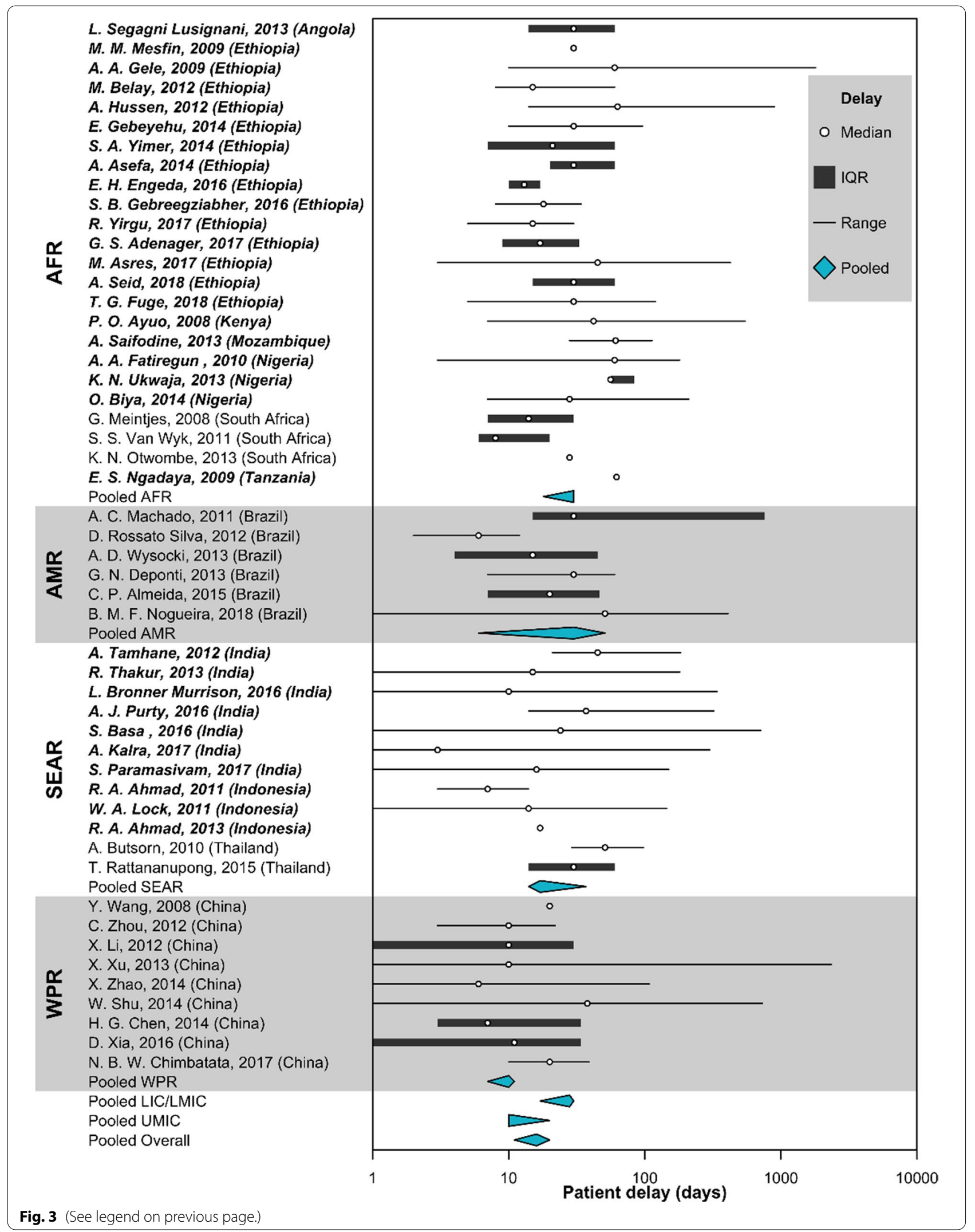


Table 2 Summary of risk factors for patient delay, health system delay, and treatment delay in high TB burden countries

\begin{tabular}{|c|c|c|c|c|c|c|c|c|}
\hline \multirow[t]{3}{*}{ Risk factors } & \multicolumn{8}{|c|}{ Number of studies that reported the risk factors associated with the different types of delay by economies } \\
\hline & \multicolumn{2}{|l|}{ Patient delay } & \multicolumn{2}{|c|}{ Health system delay } & \multicolumn{2}{|c|}{ Treatment delay } & \multicolumn{2}{|l|}{ Total delay } \\
\hline & LIC and LMIC & UMIC & LIC and LMIC & UMIC & LIC and LMIC & UMIC & LIC and LMIC & UMIC \\
\hline \multicolumn{9}{|c|}{ Socio-demographic and economic } \\
\hline \multicolumn{9}{|c|}{ Sex } \\
\hline Female & $3[38,39,61]$ & $4[21,69,82,83]$ & & 1[69] & & & $1[108]$ & \\
\hline Male & $3[56,58,62]$ & $1[86]$ & & & & & $3[60,102,107]$ & \\
\hline \multicolumn{9}{|l|}{ Age } \\
\hline Older age & $5[27,30,31,40,61]$ & $3[20,21,74]$ & & $1[92]$ & $3[48,93,95]$ & & $\begin{array}{l}5[34,47,60,107, \\
108]\end{array}$ & \\
\hline Younger age & & & & $1[72]$ & $1[94]$ & & & \\
\hline Low education & $\begin{array}{l}8[26,32,33,40,46 \\
54,58,60]\end{array}$ & $2[67,71]$ & & & & & $1[102]$ & \\
\hline \multicolumn{9}{|l|}{ Residence } \\
\hline Rural & $\begin{array}{l}7[25,26,32-34 \\
47,54]\end{array}$ & $1[21]$ & & & & & $\begin{array}{l}5[25,34,47,105, \\
108]\end{array}$ & $1[87]$ \\
\hline Urban & $3[28,60,62]$ & $1[89]$ & & & & & $1[60]$ & \\
\hline Sub-urban & & & $1[46]$ & & & & [106] & \\
\hline $\begin{array}{l}\text { In areas without } \\
\text { health centres }\end{array}$ & $1[97]$ & & & & & & & \\
\hline \multicolumn{9}{|l|}{ Marital status } \\
\hline Married & & & & & $1[94]$ & & & \\
\hline $\begin{array}{l}\text { Widowed/ } \\
\text { divorced/ } \\
\text { separated/not } \\
\text { married }\end{array}$ & $1[57]$ & $2[71,79]$ & & & $1[48]$ & & & \\
\hline \multicolumn{9}{|l|}{ Finances } \\
\hline Low income & $5[25,28,33,38,50]$ & $5[20,66,72,77,83]$ & $1[90]$ & & & $1[100]$ & $2[25,108]$ & \\
\hline High income & $2[41,62]$ & & & & & & $1[104]$ & \\
\hline $\begin{array}{l}\text { More working } \\
\text { days per week }\end{array}$ & & $1[72,77,78]$ & & $1[72]$ & & & & \\
\hline Unemployed & $3[39,40,43]$ & $3[67,69,87]$ & & & & & $1[103]$ & $1[87]$ \\
\hline $\begin{array}{l}\text { No health insur- } \\
\text { ance }\end{array}$ & & {$[72,76,77,83]$} & & & & & & \\
\hline $\begin{array}{l}\text { Cost of treatment/ } \\
\text { transport to } \\
\text { health facilities }\end{array}$ & $1[51]$ & $1[88]$ & & & & & & \\
\hline $\begin{array}{l}\text { Cost of health care } \\
\text { incurred before } \\
\text { diagnosis }\end{array}$ & & & & & $1[50]$ & & $2[103,106]$ & \\
\hline $\begin{array}{l}\text { Long distance/ } \\
\text { traveling time to } \\
\text { health facilities }\end{array}$ & $\begin{array}{l}9[29,33,35,36,43 \\
52,53,55,57]\end{array}$ & $4[20,72,77,101]$ & & $1[72]$ & $1[48]$ & & $1[60]$ & \\
\hline Larger family size & $3[27,38,49]$ & & & & & & $1[27]$ & \\
\hline \multicolumn{9}{|l|}{ Behavioural } \\
\hline \multicolumn{9}{|l|}{$\begin{array}{l}\text { Tobacco and } \\
\text { substance use }\end{array}$} \\
\hline Smoking & $1[41]$ & & & $1[81]$ & & & & \\
\hline Non-smoking & & & & & & & & $1[101]$ \\
\hline Alcohol use & & $1[87]$ & & & & & $1[104]$ & $1[87]$ \\
\hline $\begin{array}{l}\text { Recreational drug } \\
\text { use }\end{array}$ & & $1[65]$ & & & & & & $1[109]$ \\
\hline $\begin{array}{l}\text { Poor TB knowl- } \\
\text { edge }\end{array}$ & $\begin{array}{l}12[30-32,35 \\
42-44,50-52 \\
57,59]\end{array}$ & $5[68,74,79,83,84]$ & & & & $1[100]$ & $2[50,106]$ & \\
\hline
\end{tabular}


Table 2 (continued)

\begin{tabular}{|c|c|c|c|c|c|c|c|c|}
\hline \multirow[t]{3}{*}{ Risk factors } & \multicolumn{8}{|c|}{ Number of studies that reported the risk factors associated with the different types of delay by economies } \\
\hline & \multicolumn{2}{|l|}{ Patient delay } & \multicolumn{2}{|c|}{ Health system delay } & \multicolumn{2}{|c|}{ Treatment delay } & \multicolumn{2}{|l|}{ Total delay } \\
\hline & LIC and LMIC & UMIC & LIC and LMIC & UMIC & LIC and LMIC & UMIC & LIC and LMIC & UMIC \\
\hline $\begin{array}{l}\text { Poor perceived } \\
\text { benefit that TB is } \\
\text { incurable }\end{array}$ & $1[28]$ & & & & & & & \\
\hline $\begin{array}{l}\text { Poor perceived } \\
\text { severity (perceived } \\
\text { well and not sick) }\end{array}$ & $1[40]$ & & & & & & & \\
\hline Stigma & $3[29,44,61]$ & $2[76,85]$ & & & & & $1[102]$ & \\
\hline \multicolumn{9}{|l|}{ Health-seeking } \\
\hline \multicolumn{9}{|l|}{$\begin{array}{l}\text { Types of facilities } \\
\text { and providers }\end{array}$} \\
\hline $\begin{array}{l}\text { Traditional/spir- } \\
\text { itual medicine }\end{array}$ & $3[32,42,44]$ & & & & $1[93]$ & & & \\
\hline Self-medication & $5[24,27,31,50,63]$ & $1[83]$ & & & & & $1[27]$ & \\
\hline $\begin{array}{l}\text { Private health } \\
\text { practitioner }\end{array}$ & $1[32]$ & & $1[34]$ & & $1[50]$ & & $1[50]$ & \\
\hline Pharmacy & $2[32,58]$ & & & & & & & \\
\hline $\begin{array}{l}\text { Non-formal health } \\
\text { provider }\end{array}$ & $5[24,25,30,31,33]$ & & & & & & $2[50,103]$ & \\
\hline $\begin{array}{l}\text { Rural primary } \\
\text { health facility/ } \\
\text { non-DOTS } \\
\text { facility }\end{array}$ & $2[46,63]$ & & $1[46]$ & & & & $1[106]$ & $1[101]$ \\
\hline $\begin{array}{l}\text { Non-hospital/ } \\
\text { lower-level } \\
\text { facilities }\end{array}$ & & & $2[34,90]$ & $2[72,75]$ & & & $1[24]$ & \\
\hline \multicolumn{9}{|l|}{ Care-seeking } \\
\hline $\begin{array}{l}\text { Multiple care- } \\
\text { seeking prior to } \\
\text { diagnosis }\end{array}$ & $1[59]$ & & & & $2[50,51]$ & & $\begin{array}{l}5[25,27,50,103, \\
106]\end{array}$ & \\
\hline $\begin{array}{l}\text { Did not seek } \\
\text { treatment } \\
\text { because of first } \\
\text { symptoms }\end{array}$ & & $1[64]$ & & & & & & \\
\hline $\begin{array}{l}\text { Not aware } \\
\text { of other TB } \\
\text { patients around }\end{array}$ & & $1[80]$ & & & & & & \\
\hline \multicolumn{9}{|l|}{ Clinical/health services } \\
\hline \multicolumn{9}{|l|}{$\begin{array}{l}\text { Signs and symp- } \\
\text { toms }\end{array}$} \\
\hline No chest pain & $1[44]$ & & & & & & & \\
\hline Cough & & $\begin{array}{l}6[69,70,74,80, \\
86,88]\end{array}$ & & & & & & \\
\hline Chest pain & & $2[70,88]$ & & & & & & $1[109]$ \\
\hline $\begin{array}{l}\text { Cough without } \\
\text { sputum }\end{array}$ & & $1[88]$ & & & & & & \\
\hline Night sweats & & $1[74]$ & & & & & & \\
\hline Fever & & $1[88]$ & & & & & & \\
\hline No cough & & & & $1[70]$ & & & & \\
\hline No haemoptysis & & $3[74,78,80]$ & & & & & & \\
\hline No weight loss & & $1[64]$ & & & & & & \\
\hline $\begin{array}{l}\text { Pulmonary cavi- } \\
\text { ties }\end{array}$ & & $1[73]$ & & & & & & \\
\hline No cavitary lesion & & & & $1[70]$ & & & & \\
\hline
\end{tabular}


Table 2 (continued)

\begin{tabular}{|c|c|c|c|c|c|c|c|c|}
\hline \multirow[t]{3}{*}{ Risk factors } & \multicolumn{8}{|c|}{ Number of studies that reported the risk factors associated with the different types of delay by economies } \\
\hline & \multicolumn{2}{|l|}{ Patient delay } & \multicolumn{2}{|c|}{ Health system delay } & \multicolumn{2}{|c|}{ Treatment delay } & \multicolumn{2}{|l|}{ Total delay } \\
\hline & LIC and LMIC & UMIC & LIC and LMIC & UMIC & LIC and LMIC & UMIC & LIC and LMIC & UMIC \\
\hline $\begin{array}{l}\text { Shorter duration } \\
\text { of symptoms }\end{array}$ & $1[39]$ & & & & & & & \\
\hline $\begin{array}{l}\text { Presence of more } \\
\text { than } 1 \text { symptom }\end{array}$ & $1[45]$ & & & & & & & \\
\hline $\begin{array}{l}\text { Longer duration } \\
\text { of suspicious } \\
\text { symptoms }\end{array}$ & & $1[81]$ & & & & & & \\
\hline $\begin{array}{l}\text { Mild symptoms at } \\
\text { onset }\end{array}$ & & 1[72] & & & & & & \\
\hline \multicolumn{9}{|l|}{$\begin{array}{l}\text { Co-morbidities/ } \\
\text { infection }\end{array}$} \\
\hline $\begin{array}{l}\text { Presence of other } \\
\text { known medical } \\
\text { conditions }\end{array}$ & $1[42]$ & & & & & & & \\
\hline Hyperglycaemia & & $2[73,74]$ & & & & & & \\
\hline $\begin{array}{l}\text { HIV status not } \\
\text { known }\end{array}$ & & & & & $1[96]$ & & & \\
\hline HIV negative & $1[25]$ & & & & & & $1[25]$ & \\
\hline $\begin{array}{l}\text { TB-HIV co-infec- } \\
\text { tion/HIV positive }\end{array}$ & & & $2[34,90]$ & & $1[98]$ & & & $2[87,101]$ \\
\hline Not on ART & & & & $1[92]$ & & & & \\
\hline High HIV viral load & & & & $1[92]$ & & & & \\
\hline \multicolumn{9}{|l|}{$\begin{array}{l}\text { History and types } \\
\text { of TB }\end{array}$} \\
\hline No history of TB & $4[36,37,39,40]$ & $2[71,82]$ & & & $1[99]$ & & $1[103]$ & \\
\hline History of TB & & & & $1[82]$ & & & & \\
\hline Smear positive & $1[32]$ & $2[73,82]$ & & & & $2[82,101]$ & & \\
\hline Smear negative & $1[27]$ & & & $3[81,82,91]$ & $2[48,97]$ & & $1[27]$ & $1[109]$ \\
\hline $\begin{array}{l}\text { Extrapulmonary } \\
\text { TB }\end{array}$ & $2[27,34]$ & & & $1[91]$ & & & $3[24,27,34]$ & \\
\hline Retreatment cases & & & & & $5[94-98]$ & & & \\
\hline \multicolumn{9}{|l|}{ Health services } \\
\hline $\begin{array}{l}\text { Long waiting time } \\
\text { in the health } \\
\text { facility }\end{array}$ & & & $1[46]$ & & & & & \\
\hline $\begin{array}{l}\text { Untraceable con- } \\
\text { tact details (loss } \\
\text { to follow-up } \\
\text { post diagnosis) }\end{array}$ & & & & & $1[95]$ & & & \\
\hline $\begin{array}{l}\text { Absence of TB } \\
\text { diagnostic ser- } \\
\text { vices in the local } \\
\text { health facility }\end{array}$ & & & & & $1[96]$ & & & \\
\hline
\end{tabular}

The number at the normal line of type in each cell referred to the number of study/ies that reported the risk factors associated with the type of delay, respectively. The number/s in bracket indicate the source article/s. Blank cells indicate that no studies reported the respective risk factor. The studies are further grouped by economies based on World Bank classifications

$A R T$ antiretroviral therapy; DOTS directly observed treatment, short course; HIV human immunodeficiency virus; LIC low-income countries; LMIC low-middle-income countries; NTP national TB program; TB tuberculosis; UMIC upper-middle-income countries

In countries where $\mathrm{TB}$ diagnostic and treatment services are provided for free, access to TB care is further challenged by poor knowledge and awareness regarding such policies, making presumptive TB seek treatment early $[123,135]$. In addition to poor awareness about the free $\mathrm{TB}$ treatment policy, we also identified studies that 

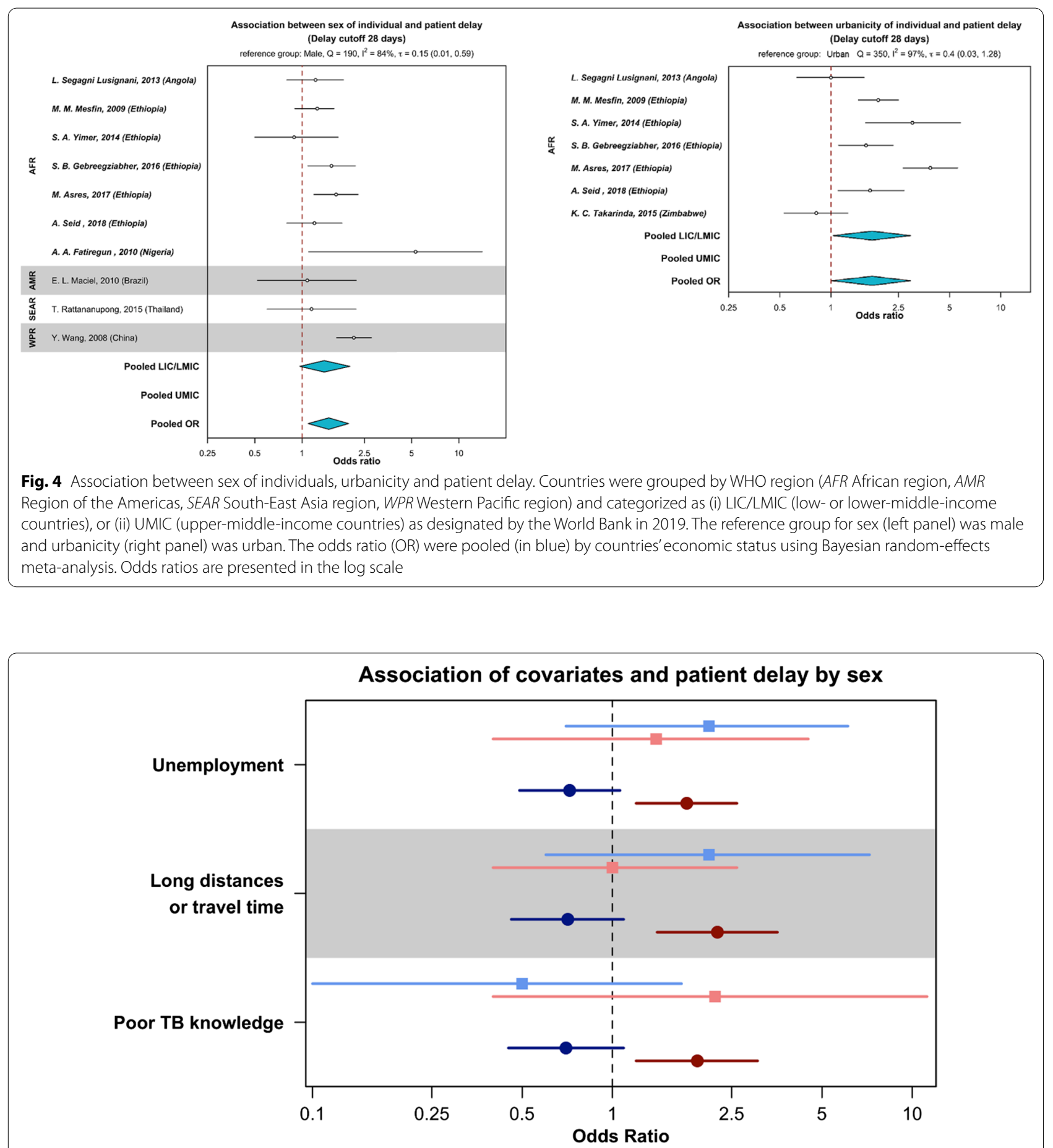

Fig. 5 Subgroup analysis of patient delay and selected covariates by sex of the individual. Tamhane et al. (2012), represented as square points, and Mfinanga et al. (2008), represented as round points, provided sex-specific association of patient delay and three covariates; i.e., being unemployed, having to travel long distances or long travelling time, and having poor TB knowledge. The sex-specific odds ratio, in the log scale, for males are presented in hues of blues and for females in hues of reds

reported poor knowledge regarding TB symptoms associated with a delay in TB care-seeking. Therefore, people with TB would delay care-seeking until only when their illness compromised their ability to work and earn livelihoods [115]. Conventionally, symptomatic individuals are linked to TB transmission, and they are regarded as the 


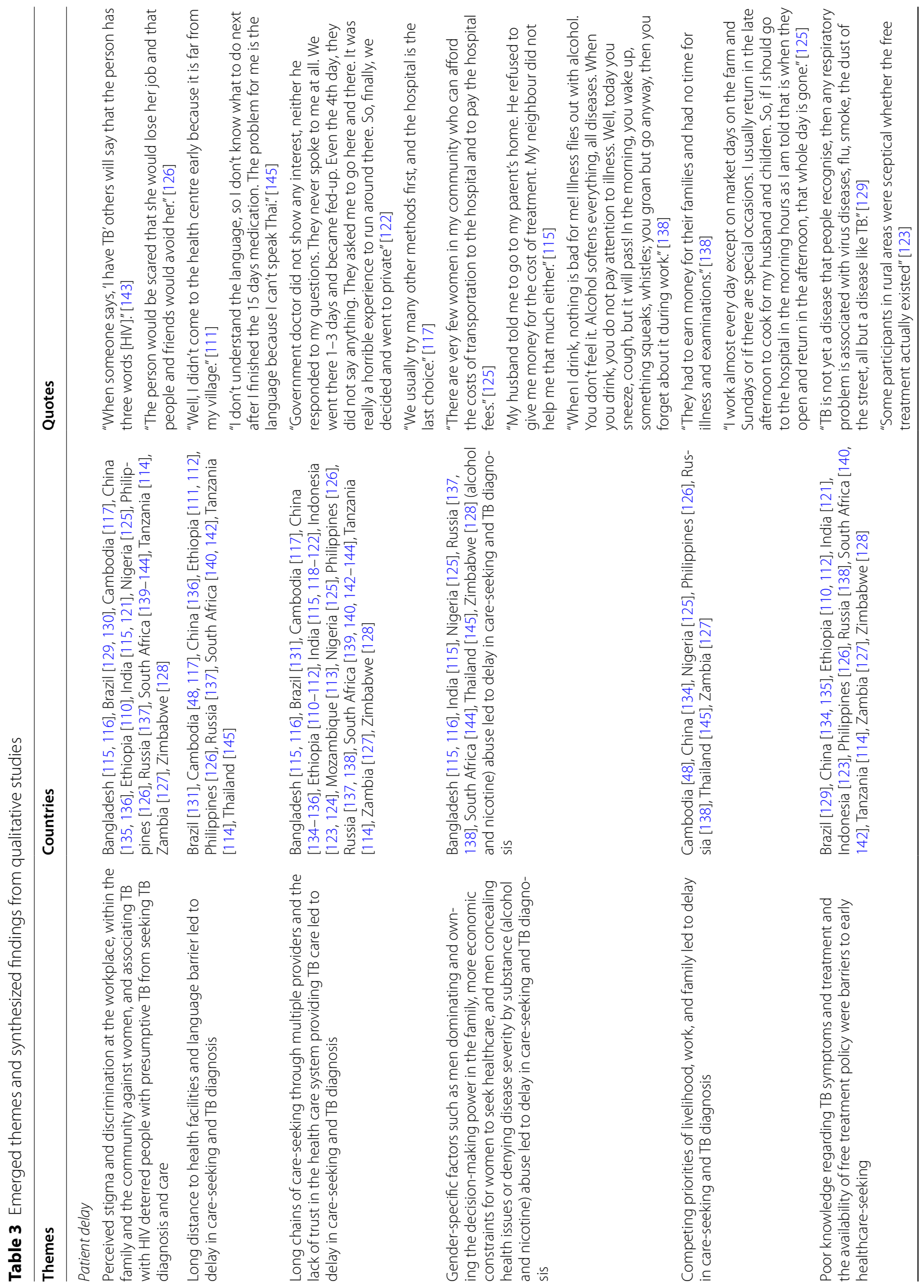




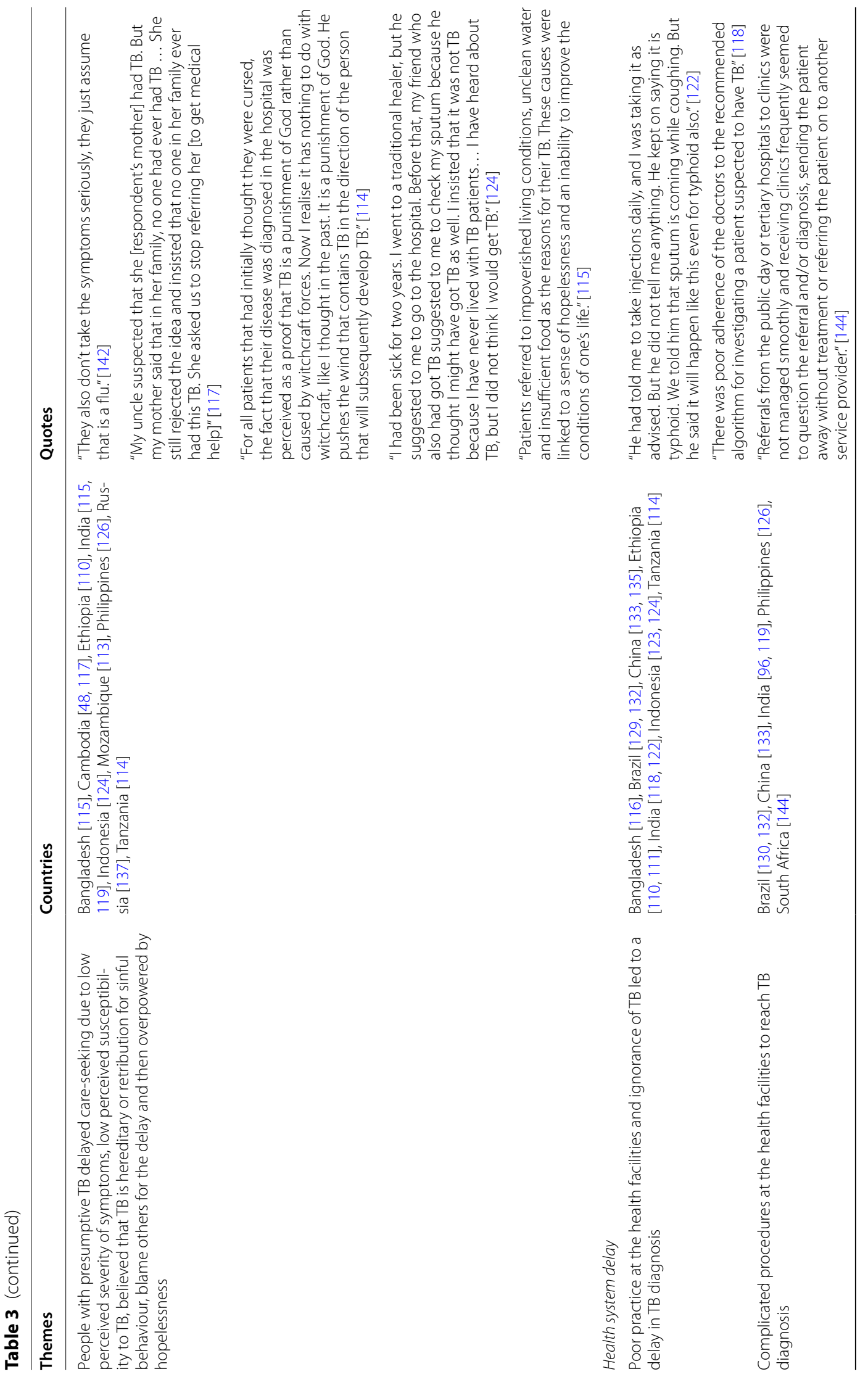




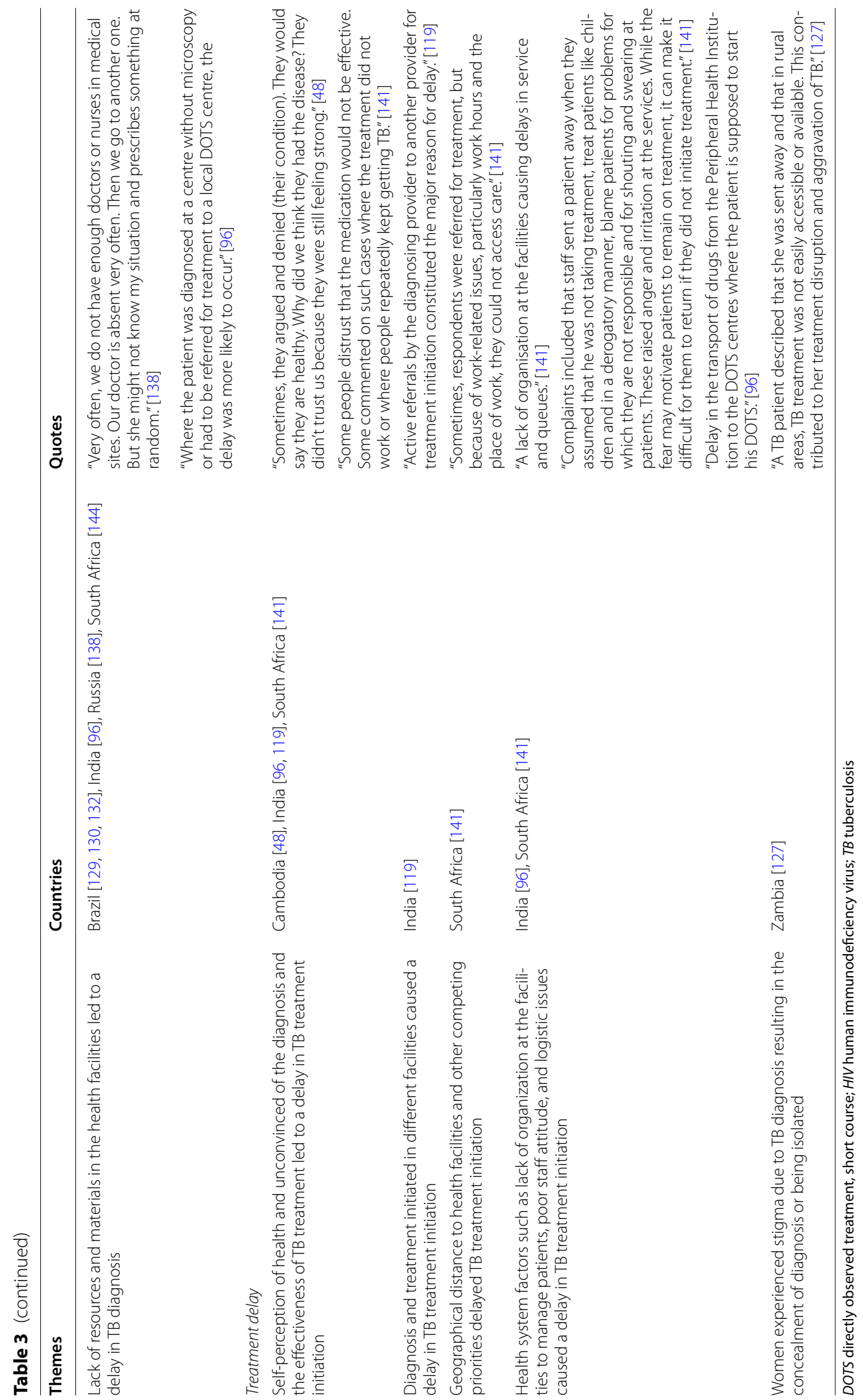




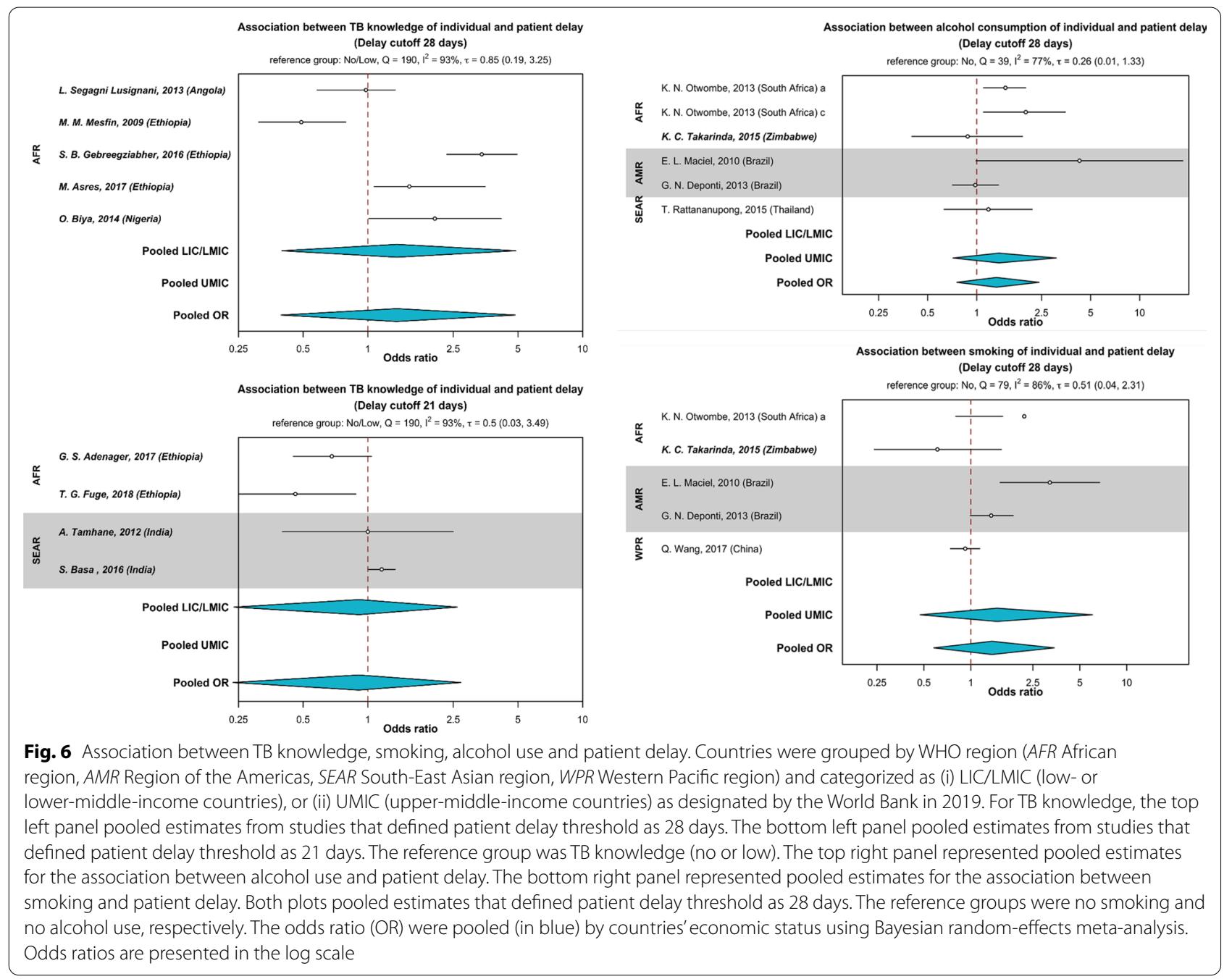

target group for TB case-finding activities using the TB symptoms screening approach [166]. However, TB transmission could also occur during the subclinical (asymptomatic) phase, particularly heightened during episodes of symptoms exhibition unrelated to TB pathologies, such as bouts of either acute or chronic cough [167]. As people with subclinical TB might not report any symptoms, they have lower awareness and motivation to seek care; thus, leading to a delay in TB diagnosis and treatment and potentially sustaining TB transmission [168] in the household and community. Therefore, a better understanding of subclinical TB, its transmission dynamics, and the implications for TB control efforts are needed. Nevertheless, individuals who exhibit TB symptoms, such as cough, are more likely to have a higher bacillary load and transmit infection $[169,170]$. Therefore, it is crucial to ensure that ill and symptomatic persons with $\mathrm{TB}$ are reached, tested, and treated promptly.
Furthermore, misperception regarding the causes of TB was also found to delay TB care-seeking. When no one in the family is ever diagnosed with TB, presumptive TB did not self-initiate care-seeking or is discouraged explicitly by family members to seek TB diagnosis and treatment [117]. Therefore, it is imperative first to measure the level of knowledge, awareness, and practices regarding $\mathrm{TB}$ in settings where studies as such have yet to be conducted. The gaps identified could then be used to develop health education programs and interventions about TB. Studies have shown that health education programs and dissemination of TB information effectively improve TB knowledge and awareness [171], enabling care-seeking and increasing the identification of TB cases [172]. Furthermore, understanding the knowledge and practices of health professionals could be done in parallel to improve care and facilitate the early identification of TB [173].

TB stigma continues to be a major barrier for people to access TB diagnosis and complete treatment $[10,143]$. 


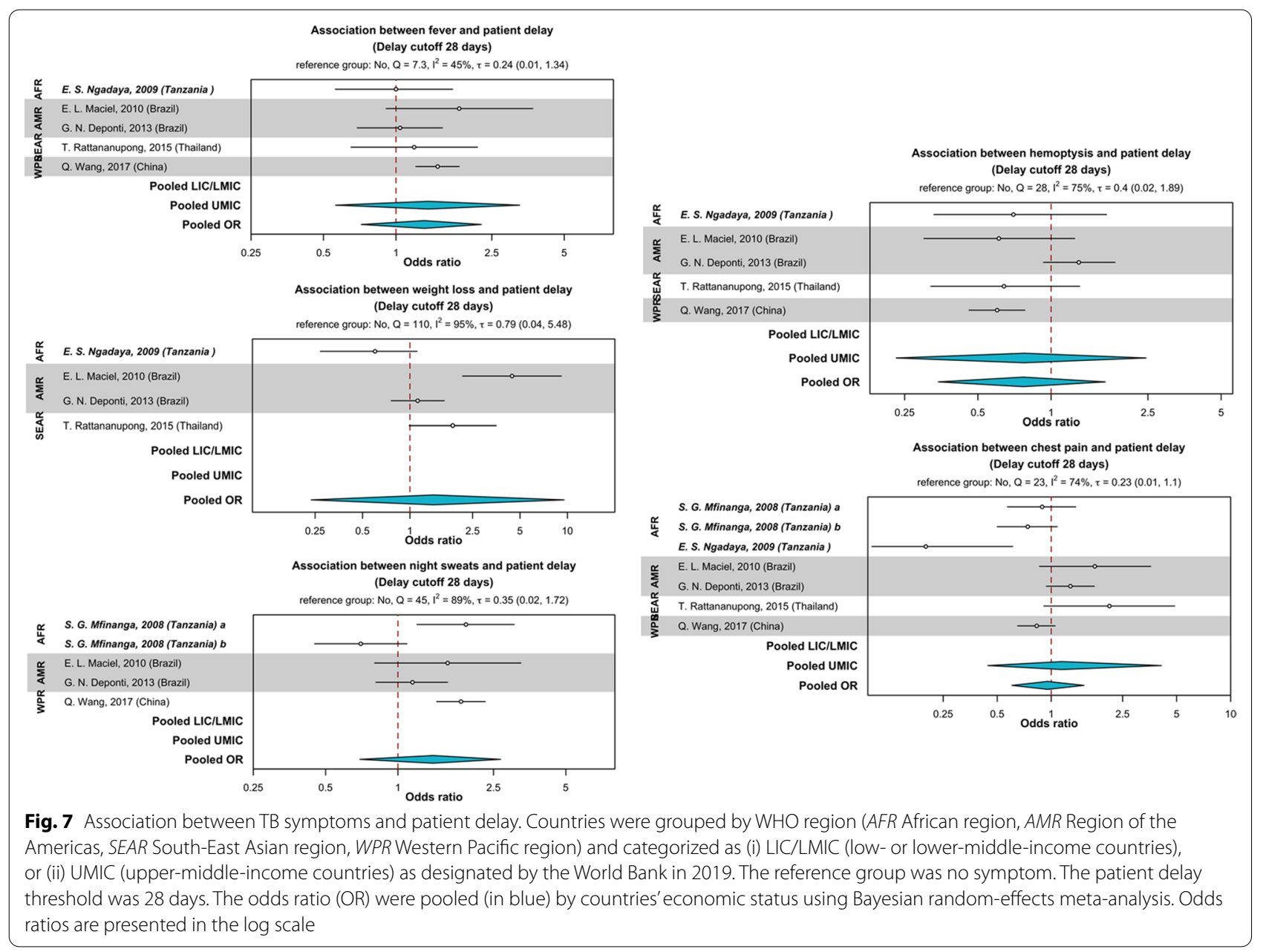

Moreover, stigma could also reduce the use of face masks $[6,174]$, further contributing to infection transmission. Despite being an increasingly important agenda of TB programs worldwide, there is a paucity of data on stigma [175], particularly information from the perpetrators of stigma [176]. There is also limited evidence on effective interventions that can reduce TB-related stigma [177]. Considering the importance of stigma reduction in TB control and elimination efforts, stigma should be systematically measured. De-stigmatisation must include approaches in healthcare institutions and beyond for a more inclusive care plan.

In high TB-burden countries, we found that people who presented with cough, fever, and night sweats were more likely to delay TB care-seeking. This is consistent with another systematic review conducted among low and middle-income countries [5]. The attribution of these symptoms to other respiratory infections or smoking and the inability to link them to TB was claimed as one of the primary reasons causing a delay in seeking care [138]. Contrarily, more severe symptoms such as hemoptysis were more likely to reduce delays in care-seeking. Therefore, education and awareness-raising activities could be recalibrated to specifically highlight the possibility of $\mathrm{TB}$ besides other respiratory illnesses in the event of more general symptoms such as cough and fever. Simultaneously, health workers' awareness on this matter in highburden settings should be raised to improve TB case findings.

\section{Health system and treatment delay}

Health system delay was more pronounced in LIC and LMIC than UMIC, likely due to the standard of health care, the strength of the national health systems, and the availability of resources. Among LIC and LMIC, a systematic review reported that the quality of health care in the public and private sectors was poor. The private sector relatively outperformed the public sector regarding the delivery of care and medicines availability [178]. The discrepancies in effectiveness and efficiency were highlighted as a facilitator to seek private healthcare, which eventually leads to a delay in TB diagnosis in a high TB 


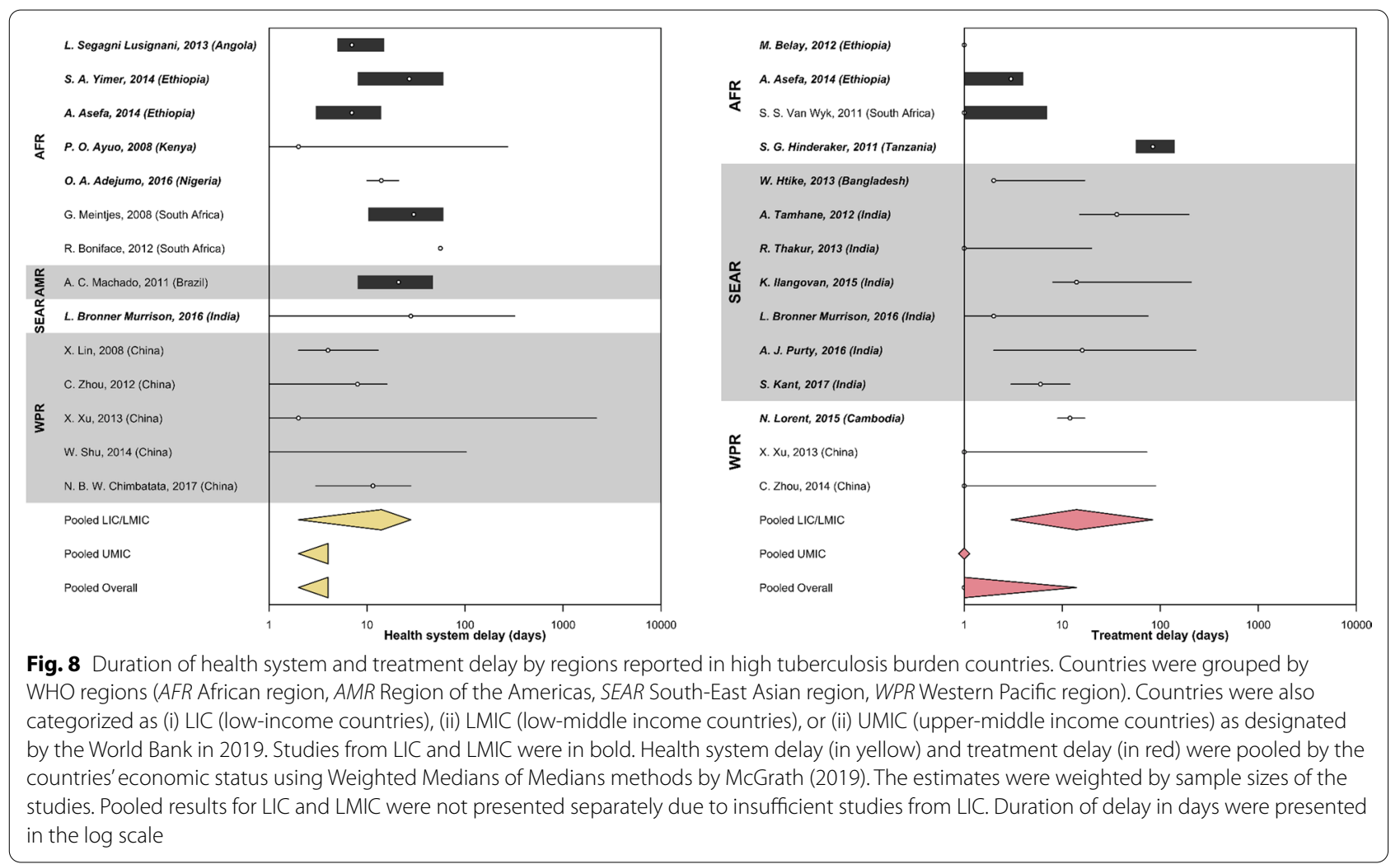

burden setting like Cambodia[179]. Narrowing down to high TB-burden countries, the quality of public and private healthcare was also found to be below par, and systematic evaluations are needed to identify gaps in the TB care pathway [157].

Likewise, treatment delay was longer in LIC and LMIC than UMIC. The delay might be due to logistic factors such as long distance to treatment centers, availability of anti-TB drugs, and the absence of TB diagnostic services in local health facilities [96, 97]. Beyond systemic factors, individuals' low perceived susceptibility and TB stigma could delay a person's decision to initiate TB treatment $[48,127]$. Interventions to decrease isolation post-diagnosis and social support should be provided to encourage prompt initiation of TB treatment [180]. Health providers also play a vital role in assisting people with TB to internalize the diagnosis and support them in decisionmaking [181].

\section{Strengths and limitations}

To our knowledge, this systematic review will be the first to focus on countries with a high TB burden, where most of the TB cases in the world [2] are found. As the list consisted of countries from LIC, LMIC, and UMIC, we attempted to discern the differences in the determinants of delayed TB diagnosis and treatment between these countries.

However, we found high levels of heterogeneity amongst the studies potentially due to clinical and methodological diversities. We included studies from different high TB-burden countries and economic statuses. While we have restricted the study populations to people with presumptive $\mathrm{TB}$ and people with $\mathrm{TB}$, their sociodemographic profiles were diverse. We acknowledged the limitation in analyzing data comprising of all possible subgroups in this review. Furthermore, we included the different observational non-randomized studies in this review. The design differed by temporality and the potential biases, contributing to methodological diversity.

In our attempt for comprehensiveness, we retained the threshold of delays as to how they were defined in individual studies. While it might not pose severe concerns for the narrative synthesis and pooling of median delays, the utilization of the delay threshold defined by individual studies in the meta-analysis of risk factors could lead to misinterpretation. Therefore, we pooled effect sizes from eligible studies that utilized similar delay thresholds in the meta-analyses. We incorporated heterogeneity into random-effects models using the Bayesian approach [23], which could yield more accurate interval estimates than conventional methods, especially for studies with a small 
sample size and are heterogenous [23, 182, 183]. However, the incorporation of heterogeneity in the randomeffects models would not fully account for the clinical and methodological diversity in the studies. Analyses of study-level covariates in a meta-regression may be relevant to further investigate heterogeneities by the differences in studies characteristics and populations. We did not perform a meta-regression in this review, and this method could be considered in future reviews of similar nature.

Nevertheless, caution in interpreting and extrapolating the findings from the meta-analyses is warranted. For the pooled median delays, the overall estimates were influenced by studies in UMIC with larger sample sizes. Therefore, we opined that the pooled estimates by economies would be more informative. In the meta-analyses of risk factors, the pooling of estimates from studies with similar delay thresholds limited the number of studies that could be included. Most of the independent variables were also grouped differently, and we could not standardize them all. Hence, the meta-analyses were only performed for selected variables. However, we strived to maintain this review's comprehensiveness by triangulating findings from narrative synthesis and thematic analyses of qualitative studies.

This review did not include data from all 30 high TBburden countries due to the absence of key outcome data and research activities. Notwithstanding the potential lack of representativeness due to the scarcity of data from several countries, this review highlights the gaps in knowledge and provides insights into the determinants of TB diagnosis and treatment delay in high-burden countries. However, the heterogeneity of the data limited the generalizability of our findings to settings underrepresented in this review.

\section{Conclusions}

Our analyses revealed a substantial delay between the onset of TB symptoms and TB care-seeking among high burden countries, highlighting the need to continue to shape knowledge, change attitude, and raise awareness of the community, people at risk of TB, and the health providers. Specific vulnerabilities such as sex disparities in care-seeking, being older, and geographic isolation should be recognized and addressed through tailored approaches to improve access to TB services and early diagnosis [184]. It is also crucial to improve the consciousness of the society regarding TB to battle stigma, and networks [185] of support from within the families, the grassroots, and institutions could create an enabling environment for early care-seeking and treatment adherence and success. In contrast to patient delay, the shorter health system and treatment delay were encouraging.
Nonetheless, TB programs should strive to test and treat TB by adopting WHO recommendations for same-day TB diagnosis [186] to further reduce TB transmission and mortality [187]. Higher-level policies and interventions such as health system strengthening, universal health coverage, and the provision of sustainable social welfare schemes are important to reduce delays, improve access to TB care, and ultimately achieve the global TB targets [188].

\section{Abbreviations \\ CASP: Critical Appraisal Skills Program; Cl: Confidence interval; HIV: Human immunodeficiency virus; HQ: High quality; LIC: Low-income countries; LMIC: Lower-middle-income countries; LQ: Low quality; MQ: Medium quality; OR: Odds ratio; PRISMA: Preferred Reporting Items for Systematic Reviews and Meta-analysis; PROSPERO: International Prospective Register of Systematic Reviews; TB: Tuberculosis; UMIC: Upper-middle-income countries; USA: Unites States of America; WHO: World Health Organization.}

\section{Supplementary Information}

The online version contains supplementary material available at https://doi. org/10.1186/s12931-021-01841-6.

Additional file 1: Table S1. Newcastle-Ottawa scale scores. Table S2. Critical Appraisal Skills Program (CASP) scores. Table S3. Computation of ConQual rating for patient delay. Table S4. Computation of ConQual score for health system delay. Table S5. Computation of ConQual score for treatment delay. Search strategy: EMBASE. Search strategy: PUBMED. Search strategy: CINAHL. Search strategy: PSYCINFO. Figure S1. Association between sex of individuals and health system delay.

\section{Acknowledgements}

We would like to thank Dr. Asano Miho for her guidance in the early part of the study and Miss Annelissa Chin and Miss Ratnala Sukanya Naidu for their assistance with developing the search terms, scanning, and retrieving articles.

\section{Authors' contributions}

AKJT, SY, LYH, and SRS conceptualized and designed the study. AKJT and SRS developed the search terms. AKJT conducted the searches. AKJT and STS screened, extracted, and verified the data. AKJT, SRS, and KP analyzed the data. KP and AKJT performed the meta-analysis. AKJT and SRS performed the systematic review and analyzed the qualitative data. AKJT, KP, and SRS prepared the tables and figures. AKJT, KP, and SRS wrote the initial draft of the manuscript. All authors read and approved the final manuscript.

Funding

The author(s) received no specific funding for this work.

Availability of data and materials

Not applicable. All data generated or analyzed during this study are included in this published article and its Additional file 1.

\section{Declarations}

Ethics approval and consent to participate

Not applicable.

Consent for publication

Not applicable.

Competing interests

The authors declare that they have no competing interests. 


\begin{abstract}
Author details
${ }^{1}$ Saw Swee Hock School of Public Health, National University of Singapore, National University Health System, Singapore, Singapore. ${ }^{2}$ Department of Infectious Disease Epidemiology, Faculty of Epidemiology and Population Health, London School of Hygiene and Tropical Medicine, London, UK. ${ }^{3}$ Yong Loo Lin School of Medicine, National University of Singapore and National University Health System, Singapore, Singapore. ${ }^{4}$ KHANA Center for Population Health Research, Phnom Penh, Cambodia. ${ }^{5}$ Center for Global Health Research, Touro University California, Vallejo, USA. ${ }^{6}$ Saw Swee Hock School of Public Health, National University of Singapore, \#10-01, 12 Science Drive 2, Singapore 117549, Singapore.
\end{abstract}

Received: 21 February 2020 Accepted: 8 September 2021

Published online: 23 September 2021

\section{References}

1. World Health Organization. TB: a global emergency, WHO report on the TB epidemic [Internet]. Geneva: World Health Organization; 1994. Available from: https://apps.who.int/iris/handle/10665/58749.

2. World Health Organization. Global tuberculosis report 2019. Geneva: World Health Organization; 2019.

3. Stop TB Partnership, United Nations Office for Project Services (UNOPS). Global plan to end TB. The paradigm shift 2016-2020. Geneva: STOP TB Partnership and UNOPS; 2016.

4. Golub JE, Bur S, Cronin WA, Gange S, Baruch N, Comstock GW, et al. Delayed tuberculosis diagnosis and tuberculosis transmission. Int J Tuberc Lung Dis. 2006;10:24-30.

5. Getnet F, Demissie M, Assefa N, Mengistie B, Worku A. Delay in diagnosis of pulmonary tuberculosis in low-and middle-income settings: systematic review and meta-analysis. BMC Pulm Med. 2017. https://doi.org/10. 1186/s12890-017-0551-y.

6. de Vries SG, Cremers AL, Heuvelings CC, Greve PF, Visser BJ, Bélard S, et al. Barriers and facilitators to the uptake of tuberculosis diagnostic and treatment services by hard-to-reach populations in countries of low and medium tuberculosis incidence: a systematic review of qualitative literature. Lancet Infect Dis. 2017;17:e128-43.

7. Sullivan BJ, Esmaili BE, Cunningham CK. Barriers to initiating tuberculosis treatment in sub-Saharan Africa: a systematic review focused on children and youth. Glob Health Action. 2017;10:1290317.

8. Sreeramareddy CT, Panduru KV, Menten J, Van den Ende J. Time delays in diagnosis of pulmonary tuberculosis: a systematic review of literature. BMC Infect Dis. 2009;9:91

9. Storla DG, Yimer S, Bjune GA. A systematic review of delay in the diagnosis and treatment of tuberculosis. BMC Public Health. 2008:8:15.

10. Barnabishvili M, Ulrichs T, Waldherr R. Role of acceptability barriers in delayed diagnosis of Tuberculosis: literature review from high burden countries. Acta Trop. 2016;161:106-13.

11. Sreeramareddy CT, Qin ZZ, Satyanarayana S, Subbaraman R, Pai M Delays in diagnosis and treatment of pulmonary tuberculosis in India: a systematic review. Int J Tuberc Lung Dis. 2014;18:255-66.

12. Page MJ, Moher D, Bossuyt PM, Boutron I, Hoffmann TC, Mulrow CD, et al. PRISMA 2020 explanation and elaboration: updated guidance and exemplars for reporting systematic reviews. BMJ. 2021. https://doi.org/ 10.1136/bmj.n160.

13. Teo AKJ, Singh SR, Prem K, Hsu LY, Yi S. Delayed diagnosis and treatment of pulmonary tuberculosis in high-burden countries: a systematic review protocol. BMJ Open. 2019;9:e029807.

14. CASP - Critical Appraisal Skills Programme. CASP Checklists [Internet]. CASP - Critical Appraisal Skills Programme. [cited 2019 Jan 26]. Available from: https://casp-uk.net/casp-tools-checklists/.

15. Noyes J, Booth A, Flemming K, Garside R, Harden A, Lewin S, et al. Cochrane Qualitative and Implementation Methods Group guidance series-paper 3: methods for assessing methodological limitations, data extraction and synthesis, and confidence in synthesized qualitative findings. J Clin Epidemiol. 2018;97:49-58.

16. Wells G, Shea B, O'connell D, Peterson J, Welch V, Losos M, et al. The Newcastle-Ottawa Scale (NOS) for assessing the quality of nonrandomised studies in meta-analyses [Internet]. [cited 2019 Jan 27].
Available from: http://www.ohri.ca/programs/clinical_epidemiology/ oxford.asp.

17. Munn Z, Porritt K, Lockwood C, Aromataris E, Pearson A. Establishing confidence in the output of qualitative research synthesis: the ConQual approach. BMC Med Res Methodol. 2014;14:108.

18. The World Bank. World Bank country and lending groups [Internet]. 2019 [cited 2019 Dec 29]. Available from: https://datahelpdesk.world bank.org/knowledgebase/articles/906519-world-bank-country-andlending-groups.

19. McGrath S, Zhao X, Qin ZZ, Steele R, Benedetti A. One-sample aggregate data meta-analysis of medians. Stat Med. 2019;38:969-84.

20. Lin X, Chongsuvivatwong V, Geater A, Lijuan R. The effect of geographical distance on TB patient delays in a mountainous province of China. Int J Tuberc Lung Dis. 2008;12:288-93.

21. Lin $Y$, Enarson DA, Chiang C-Y, Rusen ID, Qiu L-X, Kan X-H, et al. Patient delay in the diagnosis and treatment of tuberculosis in China: findings of case detection projects. Public Health Action. 2015;5:65-9.

22. Cochran WG. The combination of estimates from different experiments. Biometrics. 1954;10:101-29.

23. Higgins JPT, Thompson SG, Spiegelhalter DJ. A re-evaluation of random-effects meta-analysis. J R Stat Soc A. 2009;172:137-59.

24. Belay M, Bjune G, Ameni G, Abebe F. Diagnostic and treatment delay among tuberculosis patients in Afar Region, Ethiopia: a crosssectional study. BMC Public Health. 2012. https://doi.org/10.1186/ 1471-2458-12-369.

25. Bogale S, Diro E, Shiferaw AM, Yenit MK. Factors associated with the length of delay with tuberculosis diagnosis and treatment among adult tuberculosis patients attending at public health facilities in Gondar town, Northwest, Ethiopia. BMC Infect Dis. 2017. https://doi.org/10. 1186/s12879-017-2240-0.

26. Gebeyehu E, Azage M, Abeje G. Factors associated with patient's delay in tuberculosis treatment in Bahir Dar City Administration, Northwest Ethiopia. BioMed Res Int. 2014;2014:1-6.

27. Seid A, Metaferia Y. Factors associated with treatment delay among newly diagnosed tuberculosis patients in Dessie city and surroundings, Northern Central Ethiopia: a cross-sectional study. BMC Public Health. 2018. https://doi.org/10.1186/s12889-018-5823-9.

28. Fuge TG, Bawore SG, Solomon DW, Hegana TY. Patient delay in seeking tuberculosis diagnosis and associated factors in Hadiya Zone, Southern Ethiopia. BMC Res Notes. 2018. https://doi.org/10.1186/ s13104-018-3215-y.

29. Adenager GS, Alemseged F, Asefa H, Gebremedhin AT. Factors associated with treatment delay among pulmonary tuberculosis patients in public and private health facilities in Addis Ababa, Ethiopia. Tuberc Res Treat. 2017;2017:1-9.

30. Asres M, Gedefaw M, Kahsay A, Weldu Y. Patients' delay in seeking health care for tuberculosis diagnosis in east Gojjam Zone, Northwest Ethiopia. Am J Trop Med Hyg. 2017;96:1071-5.

31. Gebreegziabher SB, Bjune GA, Yimer SA. Patients' and health system's delays in the diagnosis and treatment of new pulmonary tuberculosis patients in West Gojjam Zone, Northwest Ethiopia: a cross-sectional study. BMC Infect Dis. 2016. https://doi.org/10.1186/s12879-016-1995-z.

32. Mesfin MM, Newell JN, Walley JD, Gessessew A, Madeley RJ. Delayed consultation among pulmonary tuberculosis patients: a cross sectional study of 10 DOTS districts of Ethiopia. BMC Public Health. 2009. https:// doi.org/10.1186/1471-2458-9-53.

33. Hussen A, Biadgilign S, Tessema F, Mohammed S, Deribe K, Deribew A. Treatment delay among pulmonary tuberculosis patients in pastoralist communities in Bale Zone, Southeast Ethiopia. BMC Res Notes. 2012. https://doi.org/10.1186/1756-0500-5-320.

34. Yimer SA, Bjune GA, Holm-Hansen C. Time to first consultation, diagnosis and treatment of TB among patients attending a referral hospital in Northwest, Ethiopia. BMC Infect Dis. 2014. https://doi.org/10.1186/ 1471-2334-14-19.

35. Gele AA, Bjune G, Abebe F. Pastoralism and delay in diagnosis of TB in Ethiopia. BMC Public Health. 2009. https://doi.org/10.1186/ 1471-2458-9-5.

36. Yirgu R, Lemessa F, Hirpa S, Alemayehu A, Klinkenberg E. Determinants of delayed care seeking for TB suggestive symptoms in Seru district, Oromiya region, Ethiopia: a community based unmatched case-control study. BMC Infect Dis. 2017. https://doi.org/10.1186/s12879-017-2407-8. 
37. Abebe G, Deribew A, Apers L, Woldemichael K, Shiffa J, Tesfaye M, et al. Knowledge, health seeking behavior and perceived stigma towards tuberculosis among tuberculosis suspects in a rural community in southwest Ethiopia. Mokrousov I, editor. PLoS ONE. 2010;5:e13339.

38. Senbeto M, Tadesse S, Tadesse T, Melesse T. Appropriate health-seeking behavior and associated factors among people who had cough for at least two weeks in northwest Ethiopia: a population-based crosssectional study. BMC Public Health. 2013. https://doi.org/10.1186/ 1471-2458-13-1222.

39. Yimer S, Holm-Hansen C, Yimaldu T, Bjune G. Health care seeking among pulmonary tuberculosis suspects and patients in rural Ethiopia: a community-based study. BMC Public Health. 2009. https://doi.org/10. 1186/1471-2458-9-454.

40. Engeda EH, Dachew BA, Kassa Woreta H, Mekonnen Kelkay M, Ashenafie TD. Health seeking behaviour and associated factors among pulmonary tuberculosis suspects in Lay Armachiho District, Northwest Ethiopia: a community-based study. Tuberc Res Treat. 2016;2016:1-7.

41. Addisu Y, Birhanu Z, Tilahun D, Assefa T. Predictors of treatment seeking intention among people with cough in East Wollega, Ethiopia based on the theory of planned behavior: a community based cross-sectional study. Ethiop J Health Sci. 2014;24:131.

42. Saifodine A, Gudo PS, Sidat M, Black J. Patient and health system delay among patients with pulmonary tuberculosis in Beira city, Mozambique. BMC Public Health. 2013. https://doi.org/10.1186/ 1471-2458-13-559.

43. Mfinanga SG, Mutayoba BK, Kahwa A, Kimaro G, Mtandu R, Ngadaya E, et al. The magnitude and factors associated with delays in management of smear positive tuberculosis in Dar es Salaam, Tanzania. BMC Health Serv Res. 2008. https://doi.org/10.1186/1472-6963-8-158.

44. Ngadaya ES, Mfinanga GS, Wandwalo ER, Morkve O. Delay in tuberculosis case detection in Pwani region, Tanzania. A cross sectional study. BMC Health Serv Res. 2009. https://doi.org/10.1186/1472-6963-9-196.

45. Senkoro M, Hinderaker SG, Mfinanga SG, Range N, Kamara DV, Egwaga $\mathrm{S}$, et al. Health care-seeking behaviour among people with cough in Tanzania: findings from a tuberculosis prevalence survey. Int J Tuberc Lung Dis. 2015;19:640-6.

46. Segagni Lusignani L, Quaglio G, Atzori A, Nsuka J, Grainger R, Da Conceiçao Palma M, et al. Factors associated with patient and health care system delay in diagnosis for tuberculosis in the province of Luanda, Angola. BMC Infect Dis. 2013. https://doi.org/10.1186/ 1471-2334-13-168.

47. Rifat M, Rusen ID, Islam MdA, Enarson DA, Ahmed F, Ahmed SM, et al. Why are tuberculosis patients not treated earlier? A study of informal health practitioners in Bangladesh. Int J Tuberc Lung Dis. 2011;15:647-51.

48. Lorent N, Choun K, Malhotra S, Koeut P, Thai S, Khun KE, et al. Challenges from tuberculosis diagnosis to care in community-based active case finding among the urban poor in Cambodia: a mixed-methods study. PLoS ONE. 2015;10:e0130179.

49. Purty A, Chauhan R, Natesan M, Cherian J, Singh Z, Sharma Y. Patient and health system delays among adult smear-positive tuberculosis patients diagnosed at medical colleges of Puducherry in south India. Indian J Public Health. 2016:60:77.

50. Thakur R, Murhekar M. Delay in diagnosis and treatment among tb patients registered under RNTCP mandi, Himachal Pradesh, India, 2010. Indian J Tuberc. 2013;60:37-45.

51. Tamhane A, Ambe G, Vermund S, Kohler CL, Karande A, Sathiakumar N. Pulmonary tuberculosis in Mumbai, India: factors responsible for patient and treatment delays. Int J Prev Med. 2012;3:13.

52. Basa S, Venkatesh S. Patient and healthcare system delays in the start of pulmonary tuberculosis treatment among tribal patients registered under DOTS, Odisha. J Clin Diagn Res [Internet]. 2016 [cited 2019 Nov 22]; Available from: http://jcdr.net/article_fulltext.asp?issn=0973-709x\& year $=2016 \&$ volume $=10 \&$ issue $=9 \&$ page $=L C 21 \& i s s n=0973-709 \times \& i d=$ 8567.

53. Kalra A. Care seeking and treatment related delay among childhood tuberculosis patients in Delhi, India. Int J Tuberc Lung Dis. 2017:21:645-50

54. Satyanarayana S, Nair SA, Chadha SS, Sharma G, Yadav S, Mohanty S, et al. Healthcare seeking among people with cough of 2 weeks or more in India. Is passive TB case finding sufficient? Public Health Action. 2012;2:157-61.

55. Lock WA, Ahmad RA, Ruiter RAC, van der Werf MJ, Bos AER, Mahendradhata Y, et al. Patient delay determinants for patients with suspected tuberculosis in Yogyakarta province, Indonesia: TB patients delay determinants. Trop Med Int Health. 2011;16:1501-10.

56. Ahmad RA, Richardus JH, de Vlas SJ. Care-seeking behaviour among individuals with TB symptoms in Jogjakarta Province, Indonesia: a community-based study. Int Health. 2013;5:51-7.

57. Ayuo P, Diero L, Owino-Ong'or W, Mwangi A. Causes of delay in diagnosis of pulmonary tuberculosis in patients attending a referral hospital in Western Kenya. East Afr Med J. 2008. https://doi.org/10.4314/eamj. v85i6.9623.

58. Njau IW, Karanja SM, Wanzala P, Omolo JO. Factors associated with late presentation of suspected tuberculosis cases to tuberculosis management facilities: the case in Dagoretti district, Nairobi, Kenya. Pan Afr Med J. 2012;12:93

59. Biya O, Gidado S, Abraham A, Waziri N, Nguku P, Nsubuga P, et al. Knowledge, care-seeking behavior, and factors associated with patient delay among newly-diagnosed pulmonary tuberculosis patients, Federal Capital Territory, Nigeria, 2010. Pan Afr Med J. 2014. https://doi.org/10. 11604/pamj.supp.2014.18.1.4166.

60. Ukwaja KN, Alobu I, Nweke CO, Onyenwe EC. Healthcare-seeking behavior, treatment delays and its determinants among pulmonary tuberculosis patients in rural Nigeria: a cross-sectional study. BMC Health Serv Res. 2013. https://doi.org/10.1186/1472-6963-13-25.

61. Fatiregun AA, Ejeckam CC. Determinants of patient delay in seeking treatment among pulmonary tuberculosis cases in a government specialist hospital in Ibadan, Nigeria. Tanzania J Health Res. 2010. https:// doi.org/10.4314/thrb.v12i2.56398.

62. Chanda-Kapata P, Kapata N, Masiye F, Maboshe M, Klinkenberg E, Cobelens $F$, et al. Health seeking behaviour among individuals with presumptive tuberculosis in Zambia. van Zyl-Smit R, editor. PLoS ONE. 2016;11:e0163975.

63. Takarinda KC, Harries AD, Nyathi B, Ngwenya M, Mutasa-Apollo T, Sandy C. Tuberculosis treatment delays and associated factors within the Zimbabwe national tuberculosis programme. BMC Public Health. 2015. https://doi.org/10.1186/s12889-015-1437-7.

64. de Almeida CPB, Skupien EC, Silva DR. Health care seeking behavior and patient delay in tuberculosis diagnosis. Cadernos de Saúde Pública. 2015;31:321-30.

65. Deponti GN, Silva DR, Coelho AC, Muller AM, de Dalcin PTR. Delayed diagnosis and associated factors among new pulmonary tuberculosis patients diagnosed at the emergency department of a tertiary care hospital in Porto Alegre, South Brazil: a prospective patient recruitment study. BMC Infect Dis. 2013. https://doi.org/10.1186/1471-2334-13-538.

66. Wysocki AD, Ponce MAZ, Scatolin BE, Andrade RL de P, Vendramini SHF, Netto AR, et al. Atraso na procura pelo primeiro atendimento para o diagnóstico da tuberculose. Revista da Escola de Enfermagem da USP. 2013:47:440-7.

67. Trigueiro DRSG, Nogueira J de A, Sá LD de, Monroe AA, Anjos UU dos, Villa TCS, et al. The influence of individual determinants in the delay of the tuberculosis diagnosis. Texto \& Contexto - Enfermagem. 2014;23:1022-31.

68. Maior M de L, Guerra RL, Cailleaux-Cezar M, Golub E, Conde MB. Time from symptom onset to the initiation of treatment of pulmonary tuberculosis in a city with a high incidence of the disease. J Bras Pneumol. 2012;38:202-9.

69. Machado AC de FT, Steffen RE, Oxlade O, Menzies D, Kritski A, Trajman A. Fatores associados ao atraso no diagnóstico da tuberculose pulmonar no estado do Rio de Janeiro. Jornal Brasileiro de Pneumologia. 2011;37:512-20.

70. Maciel ELN, Golub JE, Peres RL, Hadad DJ, Fávero JL, Molino LP, et al. Delay in diagnosis of pulmonary tuberculosis at a primary health clinic in Vitoria, Brazil. Int J Tuberc Lung Dis. 2010;14:1403-10.

71. Nogueira BMF, Rolla VC, Akrami KM, Kiene SM. Factors associated with tuberculosis treatment delay in patients co-infected with HIV in a high prevalence area in Brazil. Hasnain SE, editor. PLOS ONE. 2018;13:e0195409. 
72. Zhou C, Tobe RG, Chu J, Gen H, Wang X, Xu L. Detection delay of pulmonary tuberculosis patients among migrants in China: a crosssectional study. Int J Tuberc Lung Dis. 2012;16:1630-6.

73. Chen H-G, Liu M, Jiang S-W, Gu F-H, Huang S-P, Gao T-J, et al. Impact of diabetes on diagnostic delay for pulmonary tuberculosis in Beijing. Int $J$ Tuberc Lung Dis. 2014;18:267-71.

74. Wang Q, Ma A, Han X, Zhao S, Cai J, Kok FJ, et al. Hyperglycemia is associated with increased risk of patient delay in pulmonary tuberculosis in rural areas: 高血糖与农村地区肺结核患者延误就诊风险增加相关.」 Diabetes. 2017;9:648-55.

75. Chimbatata NBW, Zhou C, Chimbatata CM, Mhango L, Diwan VK, XU B. Barriers to prompt TB diagnosis-a comparative study between northern Malawi and eastern rural China. Trans R Soc Trop Med Hyg. 2017;111:504-11

76. Duan Q, Wang P, LV J, Zhong R, Wang W. Health care seeking among pulmonary tuberculosis suspects in Wuhan: a community-based study. Int J Med Med Sci. 2013;5:273-8.

77. Tobe RG, Xu L, Zhou C, Yuan Q, Geng H, Wang X. Factors affecting patient delay of diagnosis and completion of Direct Observation Therapy, Short-course (DOTS) among the migrant population in Shandong, China. BioSci Trends [Internet]. 2013 [cited 2019 Nov 22]; Available from: http://www.biosciencetrends.com/getabstract.php?id=678.

78. Li X, Jiang S, Li X, Mei J, Zhong Q, Xu W, et al. Predictors on delay of initial health-seeking in new pulmonary tuberculosis cases among migrants population in east China. Pai M, editor. PLoS ONE. 2012; 7:e31995.

79. Zhao X, Yang P, Gai R, Mei L, Wang X, Xu L. Determinants of health care-seeking delay among tuberculosis patients in Shandong Province, China. Eur J Public Health. 2014;24:757-61.

80. Xia D, Zhang Z, Li X, Jiang C, Ma J, Ding S, et al. Factors associated with patient delay among new tuberculosis patients in Anqing, China. Biomed Res. 2016;27:8.

81. Shu W, Chen W, Zhu S, Hou Y, Mei J, Bai L, et al. Factors causing delay of access to tuberculosis diagnosis among new, active tuberculosis patients: a prospective cohort study. Asia Pac J Public Health. 2014;26:33-41.

82. Xu X, Liu J-H, Cao S-Y, Zhao Y, Dong X-X, Liang Y, et al. Delays in care seeking, diagnosis and treatment among pulmonary tuberculosis patients in Shenzhen, China. Int J Tuberc Lung Dis. 2013;17:615-20.

83. Wang $\mathrm{Y}$, Long $\mathrm{Q}$, Liu $\mathrm{Q}$, Tolhurst $\mathrm{R}$, Tang $\mathrm{S}$. Treatment seeking for symptoms suggestive of TB: comparison between migrants and permanent urban residents in Chongqing, China: delay in treatment seeking for symptoms suggestive of TB. Trop Med Int Health. 2008;13:927-33.

84. Woith WM, Larson JL. Delay in seeking treatment and adherence to tuberculosis medications in Russia: a survey of patients from two clinics. Int J Nurs Stud. 2008:45:1163-74.

85. Møller V, Erstad I, Cramm JM, Nieboer AP, Finkenflügel H, Radloff S, et al. Delays in presenting for tuberculosis treatment associated with fear of learning one is HIV-positive. Afr J AIDS Res. 2011;10:25-36.

86. Meintjes G, Schoeman H, Morroni C, Wilson D, Maartens G. Patient and provider delay in tuberculosis suspects from communities with a high HIV prevalence in South Africa: a cross-sectional study. BMC Infect Dis. 2008. https://doi.org/10.1186/1471-2334-8-72

87. Otwombe KN, Variava E, Holmes CB, Chaisson RE, Martinson N. Predictors of delay in the diagnosis and treatment of suspected tuberculosis in HIV co-infected patients in South Africa. Int J Tuberc Lung Dis. 2013;17:1199-205

88. Butsorn A, Suggaravetsiri P, Tesama N. Delay of treatment among new smear-positive pulmonary tuberculosis patients in Thai-Cambodia border: cases study in Surin and Sisaket Province, Thailand. Res J Med Sci. 2010;4:340-5.

89. Rattananupong T, Hiransuthikul N, Lohsoonthorn V, Chuchottaworn C. Factors associated with delay in tuberculosis treatment at 10 tertiary level care hospitals in Thailand. Southeast Asian J Trop Med Public Health. 2015;46:8.

90. Adejumo OA, Daniel OJ, Otesanya AF, Adejumo EN. Determinants of health system delay at public and private directly observed treatment, short course facilities in Lagos State, Nigeria: a cross-sectional study. Int J Mycobacteriol. 2016;5:257-64.

91. Rossato Silva D, Müller AM, de Tarso Roth Dalcin P. Factors associated with delayed diagnosis of tuberculosis in hospitalized patients in a high
TB and HIV burden setting: a cross-sectional study. BMC Infect Dis. 2012. https://doi.org/10.1186/1471-2334-12-57.

92. Boniface R, Moshabela M, Zulliger R, MacPherson P, Nyasulu P. Correlates of delayed diagnosis among human immunodeficiency virusinfected pulmonary tuberculosis suspects in a rural HIV Clinic, South Africa. Tuberc Res Treat. 2012;2012:1-7.

93. Hinderaker SG, Madland S, Ullenes M, Enarson DA, Rusen I, Kamara D. Treatment delay among tuberculosis patients in Tanzania: data from the FIDELIS initiative. BMC Public Health. 2011. https://doi.org/10.1186/ 1471-2458-11-306.

94. Htike W, Islam MA, Hasan MT, Ferdous S, Rifat M. Factors associated with treatment delay among tuberculosis patients referred from a tertiary hospital in Dhaka City: a cross-sectional study. Public Health Action. 2013;3:317-22

95. Thomas BE, Subbaraman R, Sellappan S, Suresh C, Lavanya J, Lincy S, et al. Pretreatment loss to follow-up of tuberculosis patients in Chennai, India: a cohort study with implications for health systems strengthening. BMC Infect Dis. 2018. https://doi.org/10.1186/s12879-018-3039-3.

96. Paul D, Busireddy A, Nagaraja SB, Satyanarayana S, Dewan PK, Nair $S A$, et al. Factors associated with delays in treatment initiation after tuberculosis diagnosis in two districts of India. Pai M, editor. PLoS ONE. 2012; 7:e39040.

97. Kant S, Singh A, Parmeshwaran G, Haldar P, Malhotra S, Kaur R. Delay in initiation of treatment after diagnosis of pulmonary tuberculosis in primary health care setting: eight year cohort analysis from district Faridabad, Haryana, North India. Rural Remote Health. 2017. https://doi. org/10.22605/RRH4158.

98. Ilangovan K, Nagaraja SB, Ananthakrishnan R, Jacob AG, Tripathy JP, Tamang D. TB Treatment delays in Odisha, India: is it expected even after these many years of RNTCP implementation? Mistry N, editor. PLoS ONE. 2015:10:e0125465.

99. Mugauri H, Shewade HD, Dlodlo RA, Hove S, Sibanda E. Bacteriologically confirmed pulmonary tuberculosis patients: loss to follow-up, death and delay before treatment initiation in Bulawayo, Zimbabwe from 2012-2016. Int J Infect Dis. 2018;76:6-13.

100. Zhou C, Chu J, Geng H, Wang X, Xu L. Pulmonary tuberculosis among migrants in Shandong, China: factors associated with treatment delay. BMJ Open. 2014;4:e005805.

101. Van Wyk SS, Enarson DA, Beyers N, Lombard C, Hesseling AC. Consulting private health care providers aggravates treatment delay in urban South African tuberculosis patients. Int J Tuberc Lung Dis. 2011:15:1069-76.

102. Asefa A, Teshome W. Total delay in treatment among smear positive pulmonary tuberculosis patients in five primary health centers, southern Ethiopia: a cross sectional study. Pai M, editor. PLoS ONE. 2014;9:e102884.

103. Bronner Murrison L, Ananthakrishnan R, Swaminathan A, Auguesteen S, Krishnan N, Pai M, et al. How do patients access the private sector in Chennai, India? An evaluation of delays in tuberculosis diagnosis. Int J Tuberc Lung Dis. 2016;20:544-51.

104. Van Ness SE, Chandra A, Sarkar S, Pleskunas J, Ellner JJ, Roy G, et al. Predictors of delayed care seeking for tuberculosis in southern India: an observational study. BMC Infect Dis. 2017. https://doi.org/10.1186/ s12879-017-2629-9.

105. Mahendradhata Y, Syahrizal BM, Utarini A. Delayed treatment of tuberculosis patients in rural areas of Yogyakarta province, Indonesia. BMC Public Health. 2008. https://doi.org/10.1186/1471-2458-8-393.

106. Bassili A, Seita A, Baghdadi S, AlAbsi A, Abdilai I, Agboatwalla M, et al. Diagnostic and treatment delay in tuberculosis in 7 countries of the eastern Mediterranean region. Infect Dis Clin Pract. 2008;16:23-35.

107. Saqib MA, Awan IN, Rizvi SK, Shahzad MI, Mirza ZS, Tahseen S, et al. Delay in diagnosis of tuberculosis in Rawalpindi, Pakistan. BMC Res Notes. 2011. https://doi.org/10.1186/1756-0500-4-165.

108. Saqib SE, Ahmad MM, Amezcua-Prieto C, Virginia M-R. Treatment delay among pulmonary tuberculosis patients within the Pakistan National Tuberculosis Control Program. Am J Trop Med Hyg. 2018;99:143-9.

109. Coimbra I, Maruza M, de Militão-Albuquerque MFP, Moura LV, Diniz GTN, de Miranda-Filho DB, et al. Associated factors for treatment delay in pulmonary tuberculosis in HIV-infected individuals: a nested case-control study. BMC Infect Dis. 2012. https://doi.org/10.1186/ $1471-2334-12-208$ 
110. Sagbakken M, Frich JC, Bjune GA. Perception and management of tuberculosis symptoms in Addis Ababa, Ethiopia. Qual Health Res. 2008;18:1356-66.

111. Tadesse T, Demissie M, Berhane $Y$, Kebede $Y$, Abebe M. Long distance travelling and financial burdens discourage tuberculosis DOTs treatment initiation and compliance in Ethiopia: a qualitative study. BMC Public Health. 2013. https://doi.org/10.1186/1471-2458-13-424.

112. Gele AA, Sagbakken M, Abebe F, Bjune GA. Barriers to tuberculosis care: a qualitative study among Somali pastoralists in Ethiopia. BMC Res Notes. 2010. https://doi.org/10.1186/1756-0500-3-86.

113. Mindu C, López-Varela E, Alonso-Menendez Y, Mausse Y, Augusto OJ, Gondo K, et al. Caretakers' perspectives of paediatric TB and implications for care-seeking behaviours in Southern Mozambique. Graham SM, editor. PLoS ONE. 2017;12:e0182213.

114. Verhagen LM, Kapinga R, van Rosmalen-Nooijens KAWL. Factors underlying diagnostic delay in tuberculosis patients in a rural area in Tanzania: a qualitative approach. Infection. 2010;38:433-46.

115. Gosoniu GD, Ganapathy S, Kemp J, Auer C, Somma D, Karim F, et al. Gender and socio-cultural determinants of delay to diagnosis of TB in Bangladesh, India and Malawi. Int J Tuberc Lung Dis. 2008;12:848-55.

116. Bam K, Bhatt LP, Thapa R, Dossajee HK, Angdembe MR. Illness perception of tuberculosis (TB) and health seeking practice among urban slum residents of Bangladesh: a qualitative study. BMC Res Notes. 2014. https://doi.org/10.1186/1756-0500-7-572.

117. Sundaram N, James R, Sreynimol U, Linda P, Yoong J, Saly S, et al. A strong TB programme embedded in a developing primary healthcare system is a lose-lose situation: insights from patient and community perspectives in Cambodia. Health Policy Plan. 2017;32:ii32-42.

118. Purohit MR, Sharma M, Rosales-Klintz S, Lundborg CS. 'Multiple-test' approach to the laboratory diagnosis of tuberculosis-perception of medical doctors from Ujiain, India. BMC Infect Dis. 2015. https://doi.org/ 10.1186/s12879-015-1037-2

119. Mistry N, Rangan S, Dholakia Y, Lobo E, Shah S, Patil A. Durations and delays in care seeking, diagnosis and treatment initiation in uncomplicated pulmonary tuberculosis patients in Mumbai, India. Hozbor DF, editor. PLoS ONE. 2016;11:e0152287.

120. Kapoor SK, Raman AV, Sachdeva KS, Satyanarayana S. How did the TB patients reach DOTS services in Delhi? A study of patient treatment seeking behavior. Neyrolles O, editor. PLoS ONE. 2012;7:e42458.

121. McArthur E, Bali S, Khan A. Socio-cultural and knowledge-based barriers to tuberculosis diagnosis for women in Bhopal, India. Indian J Community Med. 2016:41:62.

122. Yellappa V, Lefèvre P, Battaglioli T, Devadasan N, Van der Stuyft P. Patients pathways to tuberculosis diagnosis and treatment in a fragmented health system: a qualitative study from a south Indian district. BMC Public Health. 2017. https://doi.org/10.1186/s12889-017-4627-7.

123. Rintiswati N, Mahendradhata Y, Suharna, Susilawati, Purwanta, Subronto $Y$, et al. Journeys to tuberculosis treatment: a qualitative study of patients, families and communities in Jogjakarta, Indonesia. BMC Public Health. 2009. https://doi.org/10.1186/1471-2458-9-158.

124. Dewi C, Barclay L, Passey M, Wilson S. Improving knowledge and behaviours related to the cause, transmission and prevention of Tuberculosis and early case detection: a descriptive study of community led Tuberculosis program in Flores, Indonesia. BMC Public Health. 2016. https:// doi.org/10.1186/s12889-016-3448-4.

125. Oshi DC, Oshi SN, Alobu IN, Ukwaja KN. Gender-related factors influencing women's health seeking for tuberculosis care in Ebonyi State, Nigeria. J Biosoc Sci. 2016;48:37-50.

126. Hu A, Loo E, Winch PJ, Surkan PJ. Filipino women's tuberculosis care seeking experience in an urban poor setting: a socioecological perspective. Health Care Women Int. 2012;33:29-44.

127. Cremers AL, Gerrets R, Kapata N, Kabika A, Birnie E, Klipstein-Grobusch $K$, et al. Tuberculosis patients' pre-hospital delay and non-compliance with a longstanding DOT programme: a mixed methods study in urban Zambia. BMC Public Health. 2016. https://doi.org/10.1186/ s12889-016-3771-9.

128. Mavhu W, Dauya E, Bandason T, Munyati S, Cowan FM, Hart G, et al. Chronic cough and its association with TB-HIV co-infection: factors affecting help-seeking behaviour in Harare, Zimbabwe. Trop Med Int Health. 2010. https://doi.org/10.1111/j.1365-3156.2010.02493.x.
129. de Sa LD, Barreto AJR, de Nogueira JA, Cunha FTS, Palha PF, Villa TCS. The discourse of health managers on aspects related to the delay in tuberculosis diagnosis. Revista da Escola de Enfermagem da USP. 2013;47:1165-71.

130. Furlan MCR, Silva RLST, Marcon SS. Factors associated with early and late diagnosis of tuberculosis: a descriptive study. Online Braz J Nurs. 2014;13:62-71.

131. de Andrade SLE, de Souza Rodrigues DC, Barreto AJR, de Oliveira AAV, do Nascimento Santos ARB, de Sa LD. Tuberculosis among the elderly: health care system gateway and late diagnosis. Revista Enfermagem UERJ. 2016. https://doi.org/10.12957/reuerj.2016.5702.

132. Oliveira AAV de, Sá LD de, Nogueira J de A, Andrade SLE de, Palha PF, Villa TCS. Diagnóstico da tuberculose em pessoas idosas: barreiras de acesso relacionadas aos serviços de saúde. Revista da Escola de Enfermagem da USP. 2013;47:145-51.

133. Strand MA, Duan X, Johnson R, Li Y. Social determinants of delayed diagnosis of tuberculosis in a North China urban setting. Int Q Community Health Educ. 2011;31:279-90.

134. Wei X, Chen J, Chen P, Newell JN, Li H, Sun C, et al. Barriers to TB care for rural-to-urban migrant TB patients in Shanghai: a qualitative study. Trop Med Int Health. 2009;14:754-60.

135. Long Q, Li Y, Wang Y, Yue Y, Tang C, Tang S, et al. Barriers to accessing TB diagnosis for rural-to-urban migrants with chronic cough in Chongqing, China: a mixed methods study. BMC Health Serv Res. 2008. https://doi.org/10.1186/1472-6963-8-202.

136. Hutchison C, Khan MS, Yoong J, Lin X, Coker RJ. Financial barriers and coping strategies: a qualitative study of accessing multidrug-resistant tuberculosis and tuberculosis care in Yunnan, China. BMC Public Health. 2017. https://doi.org/10.1186/s12889-017-4089-y.

137. Kuznetsov VN, Grjibovski AM, Mariandyshev AO, Johansson E, Enarson DA, Bjune GA. Hopelessness as a basis for tuberculosis diagnostic delay in the Arkhangelsk region: a grounded theory study. BMC Public Health 2013. https://doi.org/10.1186/1471-2458-13-712.

138. Kuznetsov VN, Grjibovski AM, Mariandyshev AO, Johansson E, Bjune GA Two vicious circles contributing to a diagnostic delay for tuberculosis patients in Arkhangelsk. Emerg Health Threats J. 2014;7:24909.

139. Adams LV, Basu D, Grande SW, Craig SR, Patridge MT, Panth N, et al. Barriers to tuberculosis care delivery among miners and their families in South Africa: an ethnographic study. Int J Tuberc Lung Dis. 2017;21:571-8.

140. Finnie RKC, Mabunda T, Khoza LB, van den Borne B, Selwyn B, Mullen PD. Pilot study to develop a rapid assessment of tuberculosis careseeking and adherence practices in rural Limpopo Province, South Africa. Int Q Community Health Educ. 2011;31:3-19.

141. Skinner D, Claassens M. It's complicated: why do tuberculosis patients not initiate or stay adherent to treatment? A qualitative study from South Africa. BMC Infect Dis. 2016. https://doi.org/10.1186/ s12879-016-2054-5.

142. Kerrigan D, West N, Tudor C, Hanrahan CF, Lebina L, Msandiwa R, et al. Improving active case finding for tuberculosis in South Africa: informing innovative implementation approaches in the context of the Kharitode trial through formative research. Health Res Policy Syst. 2017. https://doi.org/10.1186/s12961-017-0206-8.

143. Murray EJ, Bond VA, Marais BJ, Godfrey-Faussett P, Ayles HM, Beyers N. High levels of vulnerability and anticipated stigma reduce the impetus for tuberculosis diagnosis in Cape Town, South Africa. Health Policy Plan. 2013;28:410-8.

144. Skordis-Worrall J, Hanson K, Mills A. Confusion, caring and tuberculosis diagnostic delay in Cape Town, South Africa. Int J Tuberc Lung Dis. 2010;14:171-80.

145. Tschirhart N, Nosten F, Foster AM. Access to free or low-cost tuberculosis treatment for migrants and refugees along the Thailand-Myanmar border in Tak province, Thailand. Int J Equity Health. 2016. https://doi. org/10.1186/s12939-016-0391-z.

146. Wingfield T, Boccia D, Tovar M, Gavino A, Zevallos K, Montoya R, et al. Defining catastrophic costs and comparing their importance for adverse tuberculosis outcome with multi-drug resistance: a prospective cohort study, Peru. PLoS Med. 2014;11:e1001675.

147. Williams E, Cheng AC, Lane GP, Guy SD. Delays in presentation and diagnosis of pulmonary tuberculosis: a retrospective study of a tertiary 
health service in Western Melbourne, 2011-2014. Intern Med J. 2018;48:184-93.

148. Abbara A, Collin SM, Kon OM, Buell K, Sullivan A, Barrett J, et al. Time to diagnosis of tuberculosis is greater in older patients: a retrospective cohort review. ERJ Open Res. 2019;5:00228-2018.

149. Lönnroth K, Castro KG, Chakaya JM, Chauhan LS, Floyd K, Glaziou P, et al. Tuberculosis control and elimination 2010-50: cure, care, and social development. Lancet. 2010;375:1814-29.

150. Watts K. Is Australia neglecting the local topography when it comes to catastrophic costs and ending tuberculosis? Trop Med Infect Dis. 2018;3:126.

151. Pareek M, Greenaway C, Noori T, Munoz J, Zenner D. The impact of migration on tuberculosis epidemiology and control in high-income countries: a review. BMC Med. 2016;14:48.

152. Lönnroth K, Migliori GB, Abubakar I, D'Ambrosio L, de Vries G, Diel R, et al. Towards tuberculosis elimination: an action framework for lowincidence countries. Eur Respir J. 2015;45:928-52.

153. Durrani $\mathrm{H}$. Healthcare and healthcare systems: inspiring progress and future prospects. Mhealth. 2016. https://doi.org/10.3978/j.issn.23069740.2016.01.03.

154. Olaru ID, Albert H, Zallet J, Werner U-E, Ahmed N, Rieder HL, et al. Impact of quality improvement in tuberculosis laboratories in low- and lower-middle-income countries: a systematic review. Int J Tuberc Lung Dis. 2018;22:309-20.

155. Sulis G, Centis R, Sotgiu G, D'Ambrosio L, Pontali E, Spanevello A, et al. Recent developments in the diagnosis and management of tuberculosis. npj Prim Care Respir Med. 2016. https://doi.org/10.1038/npjpcrm. 2016.78.

156. Horton KC, MacPherson P, Houben RMGJ, White RG, Corbett EL. Sex differences in tuberculosis burden and notifications in low- and middleincome countries: a systematic review and meta-analysis. PLoS Med. 2016. https://doi.org/10.1371/journal.pmed.1002119.

157. Cazabon D, Alsdurf H, Satyanarayana S, Nathavitharana R, Subbaraman R, Daftary A, et al. Quality of tuberculosis care in high burden countries: the urgent need to address gaps in the care cascade. Int J Infect Dis. 2017:56:111-6.

158. World Health Organization. Addressing poverty in TB control: options for national TB control programs. Geneva: World Health Organization; 2005.

159. Fuady A, Houweling TAJ, Mansyur M, Richardus JH. Catastrophic total costs in tuberculosis-affected households and their determinants since Indonesia's implementation of universal health coverage. Infect Dis Poverty. 2018;7:3.

160. Prasanna T, Jeyashree K, Chinnakali P, Bahurupi Y, Vasudevan K, Das M. Catastrophic costs of tuberculosis care: a mixed methods study from Puducherry, India. Glob Health Action. 2018. https://doi.org/10.1080/ 16549716.2018 .1477493

161. Verguet S, Riumallo-Herl C, Gomez GB, Menzies NA, Houben RMGJ, Sumner T, et al. Catastrophic costs potentially averted by tuberculosis control in India and South Africa: a modelling study. Lancet Glob Health. 2017:5:e1123-32.

162. Aljassim N, Ostini R. Health literacy in rural and urban populations: a systematic review. Patient Educ Couns. 2020;103:2142-54.

163. von Wagner C, Steptoe A, Wolf MS, Wardle J. Health literacy and health actions: a review and a framework from health psychology. Health Educ Behav. 2009;36:860-77.

164. Kuddus MA, Tynan E, McBryde E. Urbanization: a problem for the rich and the poor? Public Health Rev. 2020:41:1.

165. Li Y, Ehiri J, Tang S, Li D, Bian Y, Lin H, et al. Factors associated with patient, and diagnostic delays in Chinese TB patients: a systematic review and meta-analysis. BMC Med. 2013;11:156.

166. World Health Organization. Systematic screening for active tuberculosis: an operational guide. Geneva: World Health Organization; 2015.

167. Esmail H, Dodd PJ, Houben RMGJ. Tuberculosis transmission during the subclinical period: could unrelated cough play a part? Lancet Respir Med. 2018;6:244-6.

168. Houben RMGJ, Esmail H, Emery JC, Joslyn LR, McQuaid CF, Menzies NA, et al. Spotting the old foe-revisiting the case definition for TB. Lancet Respir Med. 2019;7:199-201.

169. Ayles H, Schaap A, Nota A, Sismanidis C, Tembwe R, Haas PD, et al, Prevalence of tuberculosis, HIV and respiratory symptoms in two
Zambian communities: implications for tuberculosis control in the era of HIV. PLOS ONE. 2009;4:e5602.

170. Turner RD, Bothamley $\mathrm{GH}$. Cough and the transmission of tuberculosis. J Infect Dis. 2015;21 1:1367-72.

171. Bisallah Cl, Rampal L, Lye M-S, Mohd Sidik S, Ibrahim N, lliyasu Z, et al. Effectiveness of health education intervention in improving knowledge, attitude, and practices regarding Tuberculosis among HIV patients in General Hospital Minna, Nigeria — a randomized control trial. PLoS ONE. 2018. https://doi.org/10.1371/journal.pone.0192276.

172. Jaramillo $E$. The impact of media-based health education on tuberculosis diagnosis in Cali, Colombia. Health Policy Plan. 2001;16:68-73.

173. Zwarenstein M, Fairall LR, Lombard C, Mayers P, Bheekie A, English RG, et al. Outreach education for integration of HIV/AIDS care, antiretroviral treatment, and tuberculosis care in primary care clinics in South Africa: PALSA PLUS pragmatic cluster randomised trial. BMJ. 2011. https://doi. org/10.1136/bmj.d2022.

174. Gonzalez-Angulo Y, Geldenhuys H, Van As D, Buckerfield N, Shea J, Mahomed $\mathrm{H}$, et al. Knowledge and acceptability of patient-specific infection control measures for pulmonary tuberculosis. Am J Infect Control. 2013:41:717-22.

175. Craig GM, Daftary A, Engel N, O'Driscoll S, loannaki A. Tuberculosis stigma as a social determinant of health: a systematic mapping review of research in low incidence countries. Int J Infect Dis. 2017;56:90-100.

176. Meershoek A, Zwerling A, Daftary A, Citro B, Smyth C, Lewis D, et al. TB stigma measurement guidance. Den Haag: KNCV Tuberculosis Foundation; 2018.

177. Sommerland N, Wouters E, Mitchell EMH, Ngicho M, Redwood L, Masquillier $C$, et al. Evidence-based interventions to reduce tuberculosis stigma: a systematic review. Int J Tuberc Lung Dis. 2017;21:S81-86.

178. Berendes S, Heywood P, Oliver S, Garner P. Quality of private and public ambulatory health care in low and middle income countries: systematic review of comparative studies. Jenkins $R$, editor. PLoS Med. 2011;8:e1000433.

179. Teo AKJ, Ork C, Eng S, Sok N, Tuot S, Hsu LY, et al. Determinants of delayed diagnosis and treatment of tuberculosis in Cambodia: a mixedmethods study. Infect Dis Poverty. 2020;9:49.

180. Johansson E, Winkvist A. Trust and transparency in human encounters in tuberculosis control: lessons learned from Vietnam. Qual Health Res. 2002;12:473-91.

181. Deber RB, Kraetschmer N, Irvine J. What role do patients wish to play in treatment decision making? Arch Intern Med. 1996;156:1414-20.

182. Bodnar O, Link A, Arendacká B, Possolo A, Elster C. Bayesian estimation in random effects meta-analysis using a non-informative prior. Stat Med. 2017;36:378-99.

183. Hartung J, Knapp G. A refined method for the meta-analysis of controlled clinical trials with binary outcome. Stat Med. 2001;20:3875-89.

184. Teo AKJ, Prem K, Tuot S, Ork C, Eng S, Pande T, et al. Mobilising community networks for early identification of tuberculosis and treatment initiation in Cambodia: an evaluation of a seed-and-recruit model. ERJ Open Res. 2020;6:00368-2019.

185. Daftary A, Frick M, Venkatesan N, Pai M. Fighting TB stigma: we need to apply lessons learnt from HIV activism. BMJ Global Health. 2017:2:e000515.

186. World Health Organization. Same-day diagnosis of tuberculosis by microscopy: policy statement. [Internet]. Geneva: World Health Organization; 2011 [cited 2020 Jan 29]. Available from: http://whqlibdoc.who. int/publications/2011/9789241501606_eng.pdf.

187. Davis JL, Dowdy DW, den Boon S, Walter ND, Katamba A, Cattamanchi A. Test and treat: a new standard for smear-positive tuberculosis. J Acquir Immune Defic Syndr. 2012;61:e6-8.

188. Lönnroth K, Glaziou P, Weil D, Floyd K, Uplekar M, Raviglione M. Beyond UHC: monitoring health and social protection coverage in the context of tuberculosis care and prevention. PLoS Med. 2014. https://doi.org/10 1371/journal.pmed.1001693.

\section{Publisher's Note}

Springer Nature remains neutral with regard to jurisdictional claims in published maps and institutional affiliations. 